\title{
Kontakty Fiodora Dostojewskiego z wydawcami
}

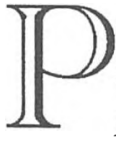

rzez cale życie ani razu nie sprzedalem utworu nie biorac pieniędzy $z$ góry. Jestem pisarzem - proletariuszem i jeżeli ktoś chce mojej pracy, to musi oplacic mnie z góry. Przeklinam ten system, ale to juz weszlo w zwyczaj $i$ chyba się nie zmieni ( $\mathrm{z}$ listu do Nikolaja Strachova z 1863 roku). „...Powiem panu [jednak] otwarcie, że nigdy nie wymyślitem tematu dla pieniędzy, dla przyjętego na siebie obowiqzku napisania w terminie. Zawsze zobowiazywatem się i zaprzedawalem, kiedy mialem już w glowie temat, który naprawdę chcialem pisać $i$ uważalem to za potrzeb$n e^{\prime \prime}$ (do tego samego adresata, 1870 rok). ${ }^{1}$ Te dwa przytoczone fragmenty $\mathrm{z}$ korespondencji pisarza jednoznacznie wskazuja, jak wielki wpływ wywierały pieniądze na rozwój twórczości Fiodora Dostojewskiego (1821-1881). Wpływ ten odcisnął swe piętno niemal na całej karierze literackiej autora „Idioty” i „Biesów”.

Jego obecność nie zmienia jednak faktu, że pisarz traktował swą pracę nie tylko w ramach zwykłej „kategorii zarobkowej” (dowiódł tego zresztą w drugiej z cytowanych powyżej wypowiedzi). Gdyby dla Fiodora Michajloviča rzeczywiście istotna byłaby każda kopiejka, to najprawdopodobniej nie poświęcałby on tyle czasu na tworzenie niezliczonych planów i wariantów przyszłych utworów, wielokrotne przekształcanie i komplikowanie niektórych epizodów. „...Dostępne nam rękopisy, listy $i<$ zapisnye kniżki> Dostojewskiego [wyraźnie] pokazuja jak uporczywie, jak tytanicznie pracowat' - pisał Boris Mejlach. ${ }^{2}$ Najlepiej chyba tę złożoną i trudną kwestię zinterpretował Boris Bursov - ,...[Zamysł] rodzil się niezależnie od pobudek materialnych, nastepnie Dostojewski oddawat w zastaw nie sprecyzowany jeszcze pomyst jakiemuś wydawcy, co wlaśnie czynilo zeń literackiego wyrobnika: $i$ wreszcie, pracujac nad utworem znajdowat natchnienie nie wyzbywając się jednak przy tym wrażenia, że pozostaje wyrobnikiem, a zatem nie osiaga w swym pisarstwie wyżyn wlasnego talentu". ${ }^{3}$

Z Badań Nad Polskimi Ksį̨gozbioram Historycznymi t. 21, Warszawa 2003. 
Istniały przynajmniej dwie ważne przyczyny, dla których Fiodor Michajlovič musiał pracować w taki sposób. Pierwszą z nich była wrodzona u niego nieumiejętność gospodarowania pieniędzmi, połączona wręcz z maniakalną skłonnością do hazardu. ,...Jeszcze w czasach nauki w Szkole Inżynieryjnej (...) potrafil przegrać jednego wieczora 1000 mbli, które [Piotr] Kariepin [opiekun nieletnich Dostojewskich] przysytat mu na caly rok" - zauważał Bohdan Urbankowski. ${ }^{4}$ Także i później - w swym dorosłym życiu - pisarz wielokrotnie oddawał się grze. Uporczywie wierzył, że wygrana zabezpieczy byt jego i rodziny, sprawi, że wreszcie uda mu się umknąć przed znienawidzonym pisaniem na zamówienie, a najlepszych idei i najlepszych pomysłów nie sprofanuje więcej pośpiech. Niestety, kolejne „pewne” systemy uzyskiwania fortuny szybko zawodziły, a nędza zmuszała Dostojewskiego do ponownego sięgnięcia po pióro. ,...W (...) pracy [notował wówczas] zamyka się teraz prawie wszystko: cate zabezpieczenie, chleb powszedni i cala moja przyszlość.".

Olbrzymie długi stanowiły drugą z przyczyn, dla których twórca „Zbrodni i kary" wcześniej pobierał od wydawców znaczne zaliczki. Pisarz zadłużony był już w latach 40-tych, na początku podjętej drogi literata, jednak prawdziwa katastrofa materialna spadła na niego w 1864 roku. Wtedy to wziął on na siebie płatności zmarłego brata Michaila (1820-1864), równocześnie próbując uchronić od bankructwa ich wspólny miesięcznik - „Epocha”. Tak pisał o tym okresie życia Fiodora Michajloviča Leonid Grossman: „...podpisuje weksle, zaspokaja pretensje wierzycieli, broni się przed protestami rejentalnymi, ratujac majatek przed sekwestrem. Każdej chwili grozi mu więzienie za diugi. Przez caly rok nie rozstaje się z petersburskimi lichwiarzami, rewirowymi, pośrednikami i urzędnikami wszelkiego typu $i$ rangi; wśród wierzycieli Dostojewskiego sa petersburskie kupcowe, notariusze, wojskowi w stanie spoczynku, nawet jakis chlop". "O tym, jak ciężko było wówczas pisarzowi, świadczy jego list z 1865 roku do Aleksandra Vrangelja (1833 - ?): „...O mój przyjacielu, z chęcia znów poszedlbym na katorgę na tyle samo lat, byle tylko splacić dtugi i znów poczuć się wolnym czlowiekiem. Teraz znów zacznę pisać powieść, mając nóż na gardle, czyli z nędzy, w pospiechu". ${ }^{7}$

Przez wszystkie lata działalności literackiej Fiodor Dostojewski śmiało rzucał wyzwania tym trudnym dla siebie okolicznościom. Udawało mu się osiągnąć to, ku czemu zmierzał, przystosowując się do niesprzyjających warunków. Środkiem, umożliwiającym mu ochronę niezależności był jego geniusz, który potrafił czerpać korzyść nawet z zewnętrznego przymusu. 


\section{Pierwodruki - wspólpraca Dostojewskiego z redaktorami czasopism i almanachów.}

\section{Ivan Pesockij i Vasilij Meževič - „Repertuar i panteon”}

„...Powinieneś wiedzieć, że (...) przethumaczylem „Eugenie Grandet” Balzaca (cudo! cudo!). Przekład niezrównany! Z pewnościq dadza mi za niego 350 rubli asygnacjami" - powiadamiał Dostojewski brata Michaila na początku 1844 roku. ${ }^{8}$ Utwór ten - pierwsza opublikowana drukiem praca pisarza - ukazał się w 6 i 7 zeszycie czasopisma "Repertuar i panteon". ${ }^{9}$ Wymienioną wyżej sumę 350 rubli (lub niewiele od niej niższa) Fiodor Michajlovič najprawdopodobniej otrzymał, nadal bowiem zamierzał kontynuować współpracę $\mathrm{z}$ redaktorami tego dwutygodnika. ${ }^{10} \mathrm{Z}$ myślą o ,Repertuarze i panteonie” tłumaczył wówczas powieść George Sand „Ostatnią z Aldinich”, snuł też olbrzymie plany zamieszczenia w nim „całego Schillera” w przekładzie brata. Tak się jednak złożyło, że „Eugenia Grandet” była pierwszym i ostatnim dziełem wydrukowanym w periodyku Ivana Pesockogo (zm. 1849 r.) i Vasilija Meževiča(1813-1849). Redakcja odmówiła bowiem najpierw publikacji Schillera, a następnie zrezygnowała $\mathrm{z}$ kupna „Ostatniej z Aldinich”, motywując to faktem, że właśnie ta książka autorstwa francuskiej pisarki pojawiła się już raz - w roku 1837 - w przekładzie rosyjskim. ${ }^{11}$

Tłumaczenie Balzaca okazało się dla Dostojewskiego ,...prawdziwa szkola praktycznym seminarium sztuki pisania powieści. Ta malo znana, debiutancka praca (...) świadczy o tym, że ten nowicjusz w literaturze śmialo i pewnie panowal już nad materiq slowa, zyskujac sobie prawo wkroczenia w szranki wielkiego pisarstwa". ${ }^{12}$

\section{Nikolaj Niekrasow - „Peterburgskij sbornik”, „Pervoe aprelja”, „Sovre- mennik" i „Illjustrovannyj almanach"}

Wiosną 1845 roku Dostojewski ukończył pierwszą - oryginalną powieść zatytułowaną „Biedni ludzie”. Wokół niej skoncentrował wówczas swe plany i nadzieje. Utwór początkowo zamierzał przekazać redakcji „Otečestvennych zapisok" - petersburskiego czasopisma skupiającego wtedy najwybitniejszych literatów. Stosunkowo szybko zmienił jednak zdanie: ,... Oddasz i będziesz niezadowolony. [informował brata w liście z 24 marca 1845 roku] Po pierwsze, nawet nie przeczytaja, a jeśli nawet przeczytaja to za pót roku. 
Rękopisów maja dosyć i bez mojego. Jeśli wydrukujq to pieniędzy nie dadza. (...) Zdecydowalem sie na rozpaczliwy krok: odczekać". ${ }^{3}$ Myśl o odczekaniu okazała się tutaj nadzwyczaj trafna. Już wkrótce bowiem kariera literacka Fiodora Michajloviča potoczyła się w niezwykłym tempie.

„... Któregoś dnia [wspominał Dmitrij Grigorovič (1822-1899), który w tym czasie mieszkał z pisarzem] Dostojewski prosi mnie do swego pokoju; przed nim, na niewielkim biurku, leżal dość gruby blok papieru listowego dużego formatu, z pozaginanymi marginesami i zapetniony drobnym pismem. - Siadaj - powiedzial niezwykle podniecony. - Wlaśnie wczoraj przepisalem i chcę ci przeczytać; usiadź i nie przerywaj". ${ }^{14}$

„Biedni ludzie" zachwycili Grigoroviča. Postanowił natychmiast wręczyć ich Nikolaju Niekrasowowi (1821-1877), gromadzącemu wówczas materiały do swego kolejnego almanachu.

„... Wzięli [Grigorovič i Niekrasow] mój rękopis [pisał 1877 roku w „Dzienniku pisarza” Dostojewski] i zaczęli czytać go na próbę. (...) Przeczytawszy dziesięc stron postanowili przeczytać jeszcze dziesięć, a potem już się nie odrywajac przesiedzieli cala noc aż do rana, czytajac na glos i zmieniajac się, kiedy jeden $z$ nich się zmęczyl'. ${ }^{15}$ Debiutancki tekst pisarza wywarł silne wrażenie także i na Vissarione Belinskim (1811-1848) - słynnym krytyku i przyjacielu Niekrasowa. ,...Napisać coś takiego $w$ dwudziestym piatym roku życia może tylko geniusz, który sila przenikliwości w jednej chwili ogarnia to, na co zwyklemu czlowiekowi potrzebne jest wieloletnie doświadczenie" - mówił potem. ${ }^{16} \mathrm{~W}$ ciagu całego 1845 roku popularność Dostojewskiego stale wzrastała, a sława o nim zataczała coraz szersze kręgi.

Projektowany przez Niekrasowa almanach - „Peterburgskij sbornik” ukazał się 15 stycznia 1846 roku. Za „Biednych ludzi” (7 arkuszy drukarskich) pisarz otrzymał wówczas honorarium w wysokości 150 rubli srebrem. Ze względu na powodzenie, z jakim spotykał się zbiór, wydawca dopłacił debiutantowi dodatkowe 100 rubli. $^{17}$

Wcześniej, w listopadzie 1845 roku, Niekrasow wraz z Grigorovičem i Dostojewskim, wspólnie planowali inne przedsięwzięcie wydawnicze - czasopismo „Zuboskal”: ,...Pisemko o objętości dwóch arkuszy (...) wychodziłoby co dwa tygodnie, a mianowicie 7 i 21 każdego miesiaca. (...) Rzecz w tym, aby szydzić $i$ wyśmiewać wszystko, nie mieć litości dla nikogo, atakować teatr, gazety, stosunki towarzyskie, literature, wydarzenia uliczne, wystawy, wiadomości krajowe, wiadomości zagraniczne, slowem wszystko, zawsze w jednym duchu i jednym celu. (...) Rzecz jest to intratna, albowiem najmniej- 
szy zysk, jaki przypaść ma na mojq osobę, to 100-150 mubli miesięcznie" - pisał Fiodor Michajlovič do brata. ${ }^{18} \mathrm{Z}$ myślą o „Zuboskale” twórca „Biednych ludzi" ułożył specjalne ogłoszenie zapowiadające dwutygodnik oraz rozpoczął pracę nad utworem „Zapiski lakeja o svoem barine” (ostatecznie przeredagowanym na „Powieść w dziewięciu listach"). ${ }^{19}$ Periodyk nie ujrzał jednak światła dziennego - powodem okazał się jeden niefortunny zwrot, jakiego użył w anonsie właśnie Dostojewski.

Niepowodzenie nie zraziło wydawcy i jego dwóch współpracowników, i wiosną 1846 roku pojawił się w sprzedaży ich następny almanach ,Pervoe aprelja". Obok części niewykorzystanych materiałów z „Zuboskala", zawierał on okrojony przez cenzurę utwór „O niebezpieczeństwie pogrążania się w ambitnych snach", niebanalnie podpisany następującymi nazwiskami: Pružinin, Zuboskalov, Belopjatkin i Ko (czyli: Sprężyniec, Szczerzyzębski, Białopiętowicz i S-ka). Za pracę nad „Niebezpieczeństwami” Dostojewski otrzymał zapłatę w wysokości 25 rubli. ${ }^{20}$

Opisany powyżej zbiór satyryczny zakończył początkowy - pomyślny okres kontaktów pisarza z kręgiem Niekrasowa, Grigoroviča i Belinskogo (1845 - początek 1846 roku). Poza „Biednymi ludźmi” wszystkie inne jego utwory z lat 40-tych witano już krytycznie. Widoczne w "Sobowtórze”, czy "Gospodyni” stopniowe odchodzenie od realizmu w stronę fantastyki, eksponowanie zjawisk wyjątkowych, nienormalnych, było nie do przyjęcia przez większość współczesnych autorowi osób. Niechęć i lekceważenie dodatkowo powiększał jeszcze fakt, że poważnie zadłużony Dostojewski swymi utworami „spłacał” wówczas znienawidzonego przez krytyka Belińskiego redaktora „Otečestvennych zapisok” - Andreja Kraevskogo (1810-1889). ${ }^{21}$

Niedawni przyjaciele zaczęli teraz szydzić i kpić z Fiodora Michajloviča: „...A propos. Omal nie zapomniatem przezabawnej anegdoty o Dostojewskim. Wykorzystujac naglaca potrzebę Krajewskiego na powieść znakomicie nabral tego (...) czlowieka. [pisał Belinskij do publicysty Vasilija Botkina] Wziąt od niego ponad 4 tysiace asygnatami $i$ zawart z nim umowę, w myśl której zobowiazal się 5 grudnia dostarczyć pierwsza częśc swej nowej wielkiej powieści, 5 stycznia - drugq cześć, 5 lutego - trzecia a 5 marca - czwarta. Mija grudzień - Dostojewski nie pokazuje się u Krajewskiego, mija styczeń-także (...) wreszcie (...) pewnego pięknego poranka rozlega się dzwonek, stużacy otwiera drzwi $i$ widzi Dostojewskiego, zdejmuje $z$ niego palto i biegnie zameldować. Krajewski, ma się rozumieć, ucieszyl się i mówi: proś; stużqcy idzie do przedpokoju i... nie widzi ani kaloszy, ani palta, ani samego Dostojewskiego". ${ }^{22}$ Takich plotek po Petersburgu krążyło 
kilka. Wkrótce pojawił się także pamflet „Vitjaz’ gorestnoj figury” oraz historia ze słynną ramką, której odurzony sławą pisarz zażądał ponoć dla otoczenia każdej strony „Biednych ludzi”. ${ }^{23}$

Ostateczne zerwanie stosunków z grupą Belinskogo nastąpiło w listopadzie 1846 roku. Po tym czasie tylko dwa utwory Dostojewskiego (z jedenastu powstałych do momentu aresztowania w 1849 roku za przynależność do kółka pietraszewców) ukazały się w wydawnictwach Niekrasowa. ${ }^{24}$ Pierwszym z nich była „Powieść w dziewięciu listach” zakupiona jeszcze w 1845 roku dla „Zuboskala”. Wydrukowano ją w 1 numerze (1847) czasopisma "Sovremennik" redagowanym, oprócz Nikolaja Niekrasowa przez Ivana Panaeva (1812-1862). ${ }^{25}$

Napisanie drugiej pracy dla Niekrasowa Dostojewski planował jeszcze w 1846 roku; wtedy też swoim późniejszym zwyczajem pobrał za nią zaliczkę. Tego samego roku została ona jednak oddana, ale co ciekawe, nie przez samego pisarza lecz przez Andreja Kraevskogo (zamiast honorarium wydawca spłacał długi Fiodora Michajloviča). Rosnąca nędza oraz obawa przed dalszym powiększaniem „kredytu” u redaktora „Otečestvennych zapisok” sprawiła jednak, że w 1847 roku autor „Biednych ludzi”, nie bacząc na doznane poniżenia ze strony zwolenników Belinskogo, raz jeszcze zwrócił się do Niekrasowa z prośbą o pomoc. Za otrzymane wówczas 150 rubli srebrem „odpłacił się” pół roku później opowiadaniem „Połzunkow”, wydrukowanym w ,Illjustrovannym almanachu”. ${ }^{26}$

Tak przedstawiał się pierwszy okres kontaktów wydawniczych pisarza z Nikolaem Niekrasowem, przynoszący mu doświadczenia zarówno miłe, jak i bardzo bolesne. „...Pomogły i nieporozumienia, i złożone okoliczności, $i$ życzliwi ludzie" - nadmienial później Dostojewski. ${ }^{27} \mathrm{Z}$ czasem jednak nieprzyjemne wspomnienia poszły w niepamięć, a ugruntowany w ciagu wielu lat wzajemny szacunek umożliwił obu stronom dalsze kontynuowanie współpracy.

\section{Andrej Kraevskij - „Otečestvennye zapiski”}

Andrej Kraevskij był drugim i ostatnim z wydawców pierwodruków Dostojewskiego w latach 40-tych. ${ }^{28}$ Do redaktora „Otečestvennych zapisok" pisarz trafił za pośrednictwem Belinskogo. O fakcie tym w następujących słowach donosił bratu: ,...Lecz tego samego roku [1845], już po zawarciu znajomości z Bielińskim, rozpoczqłem pracę nad druga powieściq: ",Sobowtór, czyli przygody pana Goladkina”. Bielin̉ski na poczatku 
jesieni [18]45 roku bardzo się ta moja nowa pracazainteresowal. Powiadomit o tym, nie znając jej jeszcze, Andrzeja Krajewskiego, u którego pracowal w piśmie, z którym poznal mnie i z którym umówilem się, że tę nowa powieść „, Sobowtór", po jej ukończeniu, dam dla „, Otieczestwiennych zapisek" w pierwszych miesiacach nadciagającego [18]46 roku". ${ }^{29}$

Po rekomendacji krytyka i sukcesie „Biednych ludzi” wydawca na współprace przystał chętnie. ,...Na dniach Kraevskij, usłyszawszy, że nie mam pieniędzy, poprosil mnie z pokora (!), by wziać od niego 500 rubli zaliczki" - chwalił się Fiodor Michajlovič. ${ }^{30}$ Wkrótce jednak sytuacja uległa odwróceniu - to pisarz musiał już „pokornie” prosić o nowe pieniądze.

„Sobowtór" ukazał się w lutowym numerze „Otečestvennych zapisok” w 1846 roku. Autor, za nieco ponad 10 arkuszy drukarskich, w sumie wzią 600 rubli srebrem (2100 rubli asygnacjami), z czego 500 automatycznie winien był Andreju Aleksandroviču. ${ }^{31}$ Honoraria za „Biednych ludzi” i udział w almanachu „Pervoe aprelja” dawno rozeszły się na najniezbędniejsze zakupy, spłaty oraz rozrywkę. Resztki rubli topniały w zastraszającym tempie. Dostojewski zmuszony był zaciagnaç kolejny dług. Tym razem Kraevskij do ręki dał pisarzowi niewiele - 50 rubli srebrem; wykonał za to inne sprytne posunięcie: przejął jego zobowiązania finansowe, regulując m. in. rozliczenia z Niekrasowem. ${ }^{32} \mathrm{~W}$ podobny sposób przebiegała ich cała dalsza współpraca. Wydawca nadal płacił za Fiodora Michajloviča długi oraz dawał mu „kieszonkowe” (50 rubli srebrem za miesiące, w których otrzymywał nowe „drobiazgi” - jak często nazywał autor swe ówczesne utwory). Dzięki takiemu układowi na łamach „Otečestvennych zapisok” pojawiły się: „Pan Procharczyn” (nr 10, 1846), „Gospodyni” (nr 10, 11, 1847), „Cudza żona” (nr 1, 1848), „Słabe serce” (nr 2, 1848), "Rasskazy byvalogo čeloveka”, „Otstavnoj”, „Uczciwy złodziej” (nr 4, 1848), „Choinka i ślub” (nr 9, 1848), „Zazdrosny mąż” (nr 11, 1848) oraz „Białe noce” (nr 12, 1848).

System wiecznego, stałego zadłużenia drażnił jednak autora, mierziło go, że dla „odpisania arkuszy” musi ryzykować swym jedynym kapitałem - nazwiskiem. ,...Źle jest pracować jako wyrobnik. Zgubisz [wtedy] wszystko, i talent i młodość i nadzieję, zbrzydnie Ci praca i ostatecznie staniesz się nie pisarzem, a pacykarzem" - żalił się Michailu. ${ }^{33}$ By uzyskać choć minimalną niezależność od wydawcy, Fiodor Michajlovič podjął się redagowania haseł do 5, 6 i 12 tomu „Podręcznego słownika encyklopedycznego". ${ }^{34}$

W 1849 roku Dostojewski spróbował uporządkować rozliczenia z Kraevskim: „...Andrzeju Aleksandrowiczu - proszę mi powiedzieć, czy przez cztery lata mojej pracy dla Pana nie zauważyl Pan, że nigdy nie będę $w$ stanie 
splacić moich dlugów, jeśli w dalszym ciagu będziemy stosować stary system pożyczania i odpracowywania pożyczek, jak dotad"? - pisał on w marcu. ${ }^{35}$ Ostatnim utworem sprzedanym na pokrycie zobowiązań miała być wielka powieść „Nietoczka Niezwanowa”.

Pierwsze dwa fragmenty „Nietoczki” pojawiły się w styczniowym i lutowym numerze „Otečestvennych zapisok" w 1849 roku. Dalszy druk przerwało aresztowanie pisarza (kwiecien 1849 roku). Dopiero po specjalnym podaniu Kraevskogo, III Oddział Kancelarii Jego Cesarskiej Mości (tajnej policji cara) zezwolił na sprzedaż majowego zeszytu pisma, w którym już bez nazwiska Dostojewskiego, znalazła się trzecia i w efekcie ostatnia część nigdy niedokończonego utworu. ${ }^{36}$

„...Tylko katorga oswobodzila [Fiodora Michajloviča] od tej kabaty, [stwierdzał Arkadij Dolinin] a <pańszczyźniane> potożenie w „Otečestvennych zapiskach" zapamiętat on na cale życie". ${ }^{37}$ Jednak i po odbyciu kary Dostojewski zmuszony był współpracować z Kraevskim (pertraktacje w imieniu pozostającego na zesłaniu autora prowadził brat Michail). Stało się tak wskutek odrzucenia przez redakcje "Russkogo vestnika" i "Sovremennika” rękopisu „Wsi Stiepanczykowo i jej mieszkańców”. ${ }^{38}$

Redaktor „Otečestvennych zapisok” zapłacił po 120 rubli za arkusz, a z całej kwoty 1800 rubli (za 15 arkuszy drukarskich) utargował jeszcze 100 rubli. Tekst ukazał się w 11 i 12 numerze czasopisma w 1859 roku. ${ }^{39}$

Z ofertą współpracy pisarz po raz ostatni zwrócił się do Andreja Kraevskogo w czerwcu 1865 roku. Obarczony wówczas długami swoimi, brata i pisma „Epocha", na drugi plan odsunął ambicje i sam zaproponował niezwykle trudne do spełnienia warunki, byle tylko spłacić najbardziej natarczywych wierzycieli. W zamian za 3000 zaliczki oddawał on „Otečestvennym zapiskom” przyszłą powieść „Pijaniutcy” (przekształconą w 1866 roku w „Zbrodnię i kare"”). „...W przypadku mojej śmierci [pisał wówczas Dostojewski] lub w przypadku niedostarczenia $w$ terminie rękopisu powieści zrzekam się na rzecz redakcji calkowicie wszelkich praw do wszystkich moich utworów, a więc praw do ich wydawania, odstepowania, zastawiania, czyli jednym stowem daję redakcji prawo postępowania z nimi tak, jak ze swojq wlasnościq. (...) Gdyby mój utwór nie spodobal się redaktorom „Otieczestwiennych zapisków" (lub cena wydala się im za wysoka) to maja prawo zwrócić go zatrzymujac w zastawie wszelkie prawa do moich utworów dopóty, dopóki nie splace 3000 mubli zaliczki (z 10 procentami). (...) Ponadto udzielam wydawcy ,Otieczestwiennych zapisek" prawa do odbioru honorariów za wszystkie artykuly, które gdziekolwiek i kiedykolwiek wydrukuje, do chwili, aż splacę 
owo 3000 mbli wraz z procentami" ${ }^{40}$ Redakcja odmówiła jednak pisarzowi, a swą decyzję umotywowała m. in. niemożliwością wypłacenia tak dużej sumy oraz wystarczającym na wiele miesięcy zapasem beletrystyki. ${ }^{41}$ Postać Andreja Kraevskogo i jego wydawnictw - „Otečestvennych zapisok” i "Golosa” kilkakrotnie pojawiły się w pracach Dostojewskiego. Redaktor sportretowany został w "Skrzywdzonych i poniżonych” (Aleksander Pietrowicz) i "Braciach Karamazow” (Rakitin), a oba periodyki wspominane są m. in. w artykułach: „Kalambury v žizni i literature”, ,Scena v redakcii odnoj iz stoličnych gazet” oraz w opowiadaniu „Krokodyl”. Biorąc pod uwagę fakt, jak układały się stosunki pomiędzy pisarzem a Andrejem Aleksandrovičem, nietrudno domyślić się chyba charakteru owych portretów...

\section{Grigorij Kušelev-Bezborodko - „Russkoe slovo”}

W marcu 1859 roku Dostojewski otrzymał zezwolenie na ponowne rozpoczęcie działalności literackiej. ${ }^{42}$ Pierwszym utworem, który ukazał się drukiem po powrocie z katorgi była powieść komiczna „Sen wujaszka” opublikowana w tym samym roku w piśmie Grigorija Kušeleva-Bezborodko (1832-1876) - „Russkoe slovo” (nr 3). ${ }^{43}$ O nawiązaniu kontaktów z redakcją miesięcznika tak pisał Fiodor Michajlovič w 1858 roku: ,... hrabia Kušelev zaplanowal wydawanie od przyszlego roku czasopisma „, Russkoe slovo". Jego znajomy, niejaki Pan Moller [Egor Moller (1812-1879), literat], przyszedt do brata i poprosit przez niego o mojq wspótpracę. Wiedzac, że potrzebuję pieniędzy, brat mój, nie znając moich zamiarów, lecz wiedzac, że piszę powieść wpadl na pomysl sprzedania jej przyszlemu ,, Russkomu slovu”. Dali 500 rubli zaliczki i podpisali umowę". ${ }^{44} \mathrm{Z}$ transakcji Michaila pisarz nie był przesadnie zadowolony, już wtedy przeczuwał, że same pieniądze hrabiego nie zapewnią pismu popularności - „... bez redakcji i bez oryginalności czasopismo będzie niedorzecznościa" - informował brata. ${ }^{45}$

Zgodnie z kontraktem, Dostojewski „Sen wujaszka” przysłał redakcji pod koniec 1858 roku. Honorarium ustalono na 100 rubli srebrem za arkusz drukarski (opowiadanie miało nieco ponad 5 arkuszy, więc wysłane rok wcześniej 500 rubli pokryły prawie w całości rozliczenie). ${ }^{46}$

Raz jeszcze - w kwietniu 1859 roku - pisarz otrzymał od Kušeleva pieniądze - 1000 rubli. Zaliczka ta nie dotyczyła żadnego konkretnego utworu, wypłacono ją bez określenia stawki za arkusz. Dostojewski zamierzał początkowo umieścić w „Russkim slove” bliżej nieokreśloną „wielką powieść” (mo- 
gły to być „Wspomnienia z domu umarłych”, „Skrzywdzeni i poniżeni” lub niezrealizowane: „Spowiedź” czy „Wiosenna miłość”), ostatecznie jednak oba teksty znalazły się w jego i Michaila periodyku „Vremja”, a wymieniona suma najprawdopodobniej nie została już zwrócona. ${ }^{47}$

\section{Michail Katkov - „Russkij vestnik”}

Po niefortunnym zakończeniu pertraktacji w sprawie „Wsi Stiepanczykowo i jej mieszkańców" pisarz nie przypuszczał chyba, że prawie wszystkie jego późniejsze utwory pojawią się na łamach „Russkogo vestnika" Michaila Katkova (1818-1887). ${ }^{48}$ Nawiązanie ponownej współpracy dodatkowo utrudniał fakt, że pomiędzy miesięcznikiem Katkova a czasopismami braci Dostojewskich, w pierwszej połowie lat 60-tych toczyła się zażarta polemika: „...Ich pozycja [„,Russkogo vestnika”] rażaco odbiegala od ",Vremeni" w zagadnieniach: zniesienia pańszczyzny, znaczenia szlachty, dalszego rozwoju ekonomicznego kraju, organizacji sqadów, urzędów miejskich i ziemskich. Dostojewski atakowat (...) Katkova (...) za jego gabinetowa izolacje nie tylko od narodu, ale także i od rosyjskiego spoleczeństwa, od rodzimej literatury, za jego stale uwielbienie <dojrzalych państw> Europy i za glębokq pogardę żywiona do rosyjskiej wspótczesności". ${ }^{49} \mathrm{Jemu}$ „zawdzięczał” też Fiodor Michajlovič decyzję zamknięcia „Vremeni”, jaką wydały władze, po opatrznym odebraniu dość dwuznacznego artykułu Nikolaja Strachova dotyczącego Powstania Styczniowego.

Po upadku „Epochi”, na początku 1865 roku, dług wekslowy Dostojewskiego opiewał na sumę 15000 rubli. ,... Oblegali go kredytodawcy, grozili rewirowym. <Albo pieniqdze na stót, albo za tydzień Pana mienie będzie opieczętowane i sprzedane (...), a Pan trafi do domu Tarasova [więzienia dla dłużników] - mówili" ${ }^{50}$ Pisarz spróbował ratować się ucieczką za granicę. Tam jednak jego dramat finansowy pogłębił się jeszcze bardziej. „...W ciagu 5 dni w Wiesbaden Dostojewski przegrywa w ruletkę wszystko, co posiada, z zegarkiem kieszonkowym wlacznie". ${ }^{51} \mathrm{Z}$ kupna projektowanej wtedy powieści zrezygnowały „Otečestvennye zapiski”, odmówił także „Sovremennik” i „Biblioteka dla čtenija”. W tej ciężkiej sytuacji z pomocą pisarzowi przyszła nieoczekiwanie również przebywająca w Wiesbaden, literatka i krewna żony Katkova, Natal'ja Šalikovaja (1815 - 1878), doradzając mu, by utwór zaproponował redaktorowi moskiewskiego miesięcznika. ${ }^{52}$

We wrześniu 1865 roku Fiodor Michajlovič pisał: „,..Czy mogę liczyć na umieszczenie w Pańskim piśmie „Russkij vestnik” swojej powieści? (...) Oddaję się calkowicie, w wyznaczeniu zaplaty, na Pana zdanie po przeczy- 
taniu tekstu. (...) Zmuszony jestem teraz poprosić Pana o 300 rubli. (...) Prośba o pomoc w tej trudnej dla mnie chwili (...) może mieć miejsce tylko w sytuacji, jeśli zgodzi się Pan przyjąc ma pracę". ${ }^{33}$ Po przeczytaniu listu, zawierającego też precyzyjny plan ,Zbrodni i kary” Katkov wysłał zaliczkę. W ten sposób zawiązała się ich wieloletnia współpraca, trwająca aż do śmierci Dostojewskiego.

Powieść ukazywała się w kolejnych numerach miesięcznika przez cały 1866 rok ( $\operatorname{nr} 1,2,4,6,7,8,11,12$ ). Honorarium ustalono na 150 rubli za arkusz (całość liczyła 36 arkuszy).

Praca nad „Zbrodnią i karą," pomimo codziennych kłopotów z wierzycielami i liczną rodziną brata (utrzymywaną przez pisarza po śmierci Michaila), posuwała się raczej pomyślnie. Zakłóciły ją jednak dwa wydarzenia.

Pierwsze z nich wiązało się z konfliktem, jaki pojawił się w połowie roku 1866 , pomiędzy autorem a redakcją. Katkov i drugi redaktor „Russkogo vestnika" - Nikolaj Ljubimov (1830-1897) zaprotestowali bowiem przeciw scenie czytania Ewangelii w IV części utworu, uważając, że tkwi w niej przewrotne wymieszanie dobra ze złem. Twierdzili, że u pisarza za bardzo zbliżyły się oba pojęcia, sprzeciwiali się tak bliskiemu sąsiedztwu Ewangelii i prostytutki, ewangelicznych zasad i teorii Raskolnikowa. W spornym rozdziale dopatrzyli się także śladów nihilizmu! Pomimo kilkakrotnych przekształceń tekstu, Katkov własnoręcznie wykreślił z niego znaczną część wersów dotyczących charakteru i zachowania Soni. ${ }^{54}$

Ponowne zastopowanie pracy nastapiło w październiku. Dostojewski, zmuszony warunkami kontraktu zawartego rok wcześniej z Fiodorem Stellovskim (1826-1875), porosił Katkova o miesiąc przerwy, by móc napisać obiecaną wydawcy zupełnie nową powieść - „Gracza”. Po wywiązaniu się z umowy, wrócił do „Zbrodni i kary”. Wraz z nim utwór ten współtworzyła już jednak stenografka, a wkrótce i żona Fiodora Michajloviča - Anna Snitkin (1846-1918). W podobny sposób - za pomocą zapisu stenograficznego - powstały pozostałe dzieła: „Idiota”, „Wieczny mąż”, „Biesy”, „Młodzik” i „Bracia Karamazow”.

Na przełomie 1866 i 1867 roku pisarz osobiście zaproponował Katkovovi swą nową powieść. Uzyskaną zaliczkę w wysokości 2000 rubli przeznaczył on na wydatki związane ze ślubem oraz pomoc najbliższym. Kolejne 1000 rubli otrzymane od redakcji także rozeszły się błyskawicznie: „...przez caly dzień przychodzily listy od krewnych i okazato się, że Fiodor Michajlowicz powinien dać im tysiac sto rubli, a jeszcze $w$ dodatku zaplacić Reismanowej [jednej z wierzycielek], a przecież mieliśmy zaledwie tysiqc" 
- wspominała Anna. ${ }^{55} \mathrm{~W}$ tej sytuacji najrozsądniejszym rozwiązaniem był wyjazd za granicę i tam, z dala od wierzycieli i rodziny, kontynuowanie pracy.

„... Wyjeżdzaliśmy prawie bez pieniędzy, przy czym wisiala nad nami zaliczka (3000 rubli), która wzięliśmy od Katkowa. [pisał Dostojewski w liście do poety Apollona Majkova (1821-1897) w sierpniu 1867 roku] Co prawda, liczylem na to, że za granicq wezmę się natychmiast do pracy. Co się jednak okazalo? Nic, albo raczej prawie nic do tej pory nie zrobilem $i$ dopiero teraz mam zamiar wziać się poważnie do pisania". ${ }^{6}$ Powodem opóźnienia był oczywiście odwieczny „Diabeł” - jak sam nazywał Fiodor Michajlovič swą namiętność do hazardu. ,... Zgrywatem się do ostatnich pieniędzy, ogarniala mnie goraczka - wciąz przegrywalem. Zastawilem swoje ubranie. Anna Grigoriewna zastawila wszystkie swoje suknie co do jednej. (...) Znów napisalem do Katkowa. (...) I przystat! A więc razem z tym, co przystal, wziqtem juz awansem $z$, Russkiego wiestnika" cztery tysiace rubli". ${ }^{57}$ Kolejne 500 rubli wydawca przekazał Dostojewskim w miesięcznych ratach po 100 rubli.

„...Nad planem nowej powieści myślatem od 4 do 18 grudnia [1867] wlącznie. (...) W glowie mi się kręcilo jak w mlynie. (...) Wreszcie 18 grudnia zaczalem pisać nowa powieść, a 5 stycznia (...) wyslalem do redakcji 5 rozdzialów części pierwszej (okolo 5 arkuszy). (...) Część drugq (nie napisatem jeszcze ani linijki) pod stowem honoru obiecalem przestać ostatecznie $i$ nieodwolalnie do l lutego". - informował Majkova pisarz na początku 1868 roku. ${ }^{58}$ Tak rozpoczęła się praca nad najbardziej ,uduchowionym" utworem Fiodora Michajloviča - „Idiotą".

Tekst o objętości 42 arkuszy drukarskich publikowany był w roku 1868 (nr 1,2, 4 - 12). ${ }^{59}$ Stawka nie uległa zmianie - pisarz otrzymywał po 150 rubli za każde 16 stron. Powieść nie pokryła jednak całej sumy pobranych wówczas zaliczek - łącznie wyniosły one około 7000 rubli i przed przystapieniem do kolejnej pracy, Dostojewski zalegał redakcji już ponad 1000 rubli. $^{60}$

W październiku 1870 roku pisarz zwracał się do Michaila Katkova: ,...Dzisiaj wystalem do redakcji "Russkiego wiestnika" zaledwie pierwsza polowe części pierwszej mojej [nowej] powieści „Biesy”. (...) Wszystkiego będq trzy części. Każda o objętości od 10 do 12 arkuszy. (...) Wiem, że jestem Panu bardzo wiele winien [między "Idiotą” a dostarczeniem początku „Biesów" wydawca nieregularnie nadsyłał Dostojewskiemu dalsze zaliczki]. Tajednak powieściq rozliczę się już z redakcja calkowicie". ${ }^{61}$ 
Za 1000 rubli otrzymane $\mathrm{z}$ „Russkogo vestnika” w czerwcu 1871 roku Fiodor Michajlovič powrócił do Rosji. Marzył o tym od dawna - ,...koniecznie powinienem powrócić do Rosji. [pisał już w styczniu 1869 roku] Tutaj wręcz tracę zdolność pisania ze względu na to, że nie mam obok siebie owej codzienności nieodzownej dla tworzenia, to znaczy brakuje mi rzeczywistości rosyjskiej (inspirujacej moje myśli) i samych Rosjan". ${ }^{62}$ Kontaktu z ojczyzną domagała się też rozpoczęta powieść o rewolucji rosyjskiej.

„Biesy" ukazywały się w kolejnych numerach miesięcznika przez rok 1871 (nr 1, 2, 4, 5, 7, 9, 10, 11). Nieoczekiwanie jednak praca została przerwana aż na czternaście miesięcy, a ostatnia część utworu pojawiła się dopiero w listopadzie i grudniu 1872 roku. Powodem tak długiego milczenia okazał się odrzucony przez redakcję rozdział „U Tichona” (znany także jako „Spowiedź Stawrogina"). Decyzja Katkova o usunięciu tekstu stanowiącego oś całej kompozycji, doprowadziła do zburzenia uformowanej już struktury powieści. Dostojewski kilkakrotnie przerabiał scenę gwałtu popełnionego przez Stawrogina na nieletniej Matrioszy. Łagodził drastyczne szczegóły, tworzył warianty o kompromisowych rozwiązaniach. Żadnej z propozycji redakcja nie zaakceptowała. Fiodorovi Michajlovičovi nie pozostało nic innego, jak tylko podporządkować się owemu veto i wyłączeniu spornego fragmentu. ${ }^{63}$ Ustapił jednak nie do końca, o czym świadczą ostatnie linijki rękopisu: „...Po Mikolaju Wsiewolodowiczu pozostaty podobno jakieś notatki, które nikomu nie sq znane. Szukam ich usilnie. Może je znajdę i jeśli to będzie możliwe... Finis". ${ }^{64}$

Po tym incydencie stosunki z redakcją "Russkogo vestnika” uległy ochłodzeniu. Następna powieść „Młodzik” wydrukowana została już w „Otečestvennych zapiskach” Nikolaja Niekrasowa. Dopiero po sześciu latach Dostojewski ponownie nawiązał współpracę z Katkovem. ,...Przyjąl mnie serdecznie, chociaż jednocześnie ostrożnie. [pisał Fiodor Michajlovič żonie w czerwcu 1878 roku] (...) Przy pierwszych slowach, kiedy mówilem, że pragnę uczestniczyć, twarz jego się rozjaśniła, ale gdy tylko wspomniatem o 300 miblach za arkusz i o zaliczce, to jakby go coś odmienilo, (...) myślę, że jutro (...) na pewno mi odmówi". ${ }^{65}$ Wydawca przystał jednak na warunki pisarza i wręczył mu zaliczkę w wysokości 2000 rubli.

„Bracia Karamazow” - bo ich dotyczyły pertraktacje, ukazywały się przez dwa lata - w 1879 roku (nr 1-6, 8, 9) i w 1880 roku (nr 1, 4, 7-11). Także i teraz, po konfliktach wynikłych przy „Zbrodni i karze” i „Biesach”, Dostojewskiego nie opuszczały obawy o druk powieści: „...Sqdze, $\dot{z} e w$ wyslanym tekście nie ma ani jednego nieprzyzwoitego słowa", „...ciq- 
gle mi się zwiduje, że nagle, z jakiegoś tam powodu "Russkij wiestnik" tego nie wydrukuje" - pisał w maju 1879 roku. ${ }^{\text {"6 }}$ Jego obawy się potwierdziły: kilkakrotnie musiał z redakcją „politykować” - jak sam się wyraził. Przekonywał wówczas, że niektóre opinie należą wyłącznie do bohaterów, że wyrażenie „histeryczne piski cherubinów” w ustach Diabła (scena dyskusji z Iwanem Karamazowem) nie jest niecenzuralne itp. „...Przecież $w$ innym wypadku będzie to zbyt prozaiczne i straci swój ton" - argumentował. ${ }^{67}$ I $z$ reguły tym razem wygrywał!

W listopadzie 1880 roku do wydawcy wpłynął epilog utworu. ,...A więc powieść już skończona! [obwieszczał N. Ljubimovovi] (...) Ale nie żegnam się jeszcze z Panem. Przecież mam zamiar jeszcze żyć i pisać przez dwadzieścia lat. Niech Pan mnie źle nie wspomina" ${ }^{68}$ Już wtedy planował on kontynuację „Karamazowych”, jego zamiary pokrzyżowała jednak śmierć.

„Bracia Karamazow” jako jedyny z tekstów Dostojewskiego został ostatecznie opłacony przez redakcję, dopiero po zakończeniu druku. Na początku stycznia 1881 roku „Russkij vestnik” pozostawał winien autorowi jeszcze 4200 rubli (powieść liczyła 76 arkuszy) - niestety zaległe honorarium mogła odebrać tylko wdowa po pisarzu. ${ }^{69}$

Pisarz zawsze pamiętał, jak wiele zawdzięczał Katkovovi - jego zaliczkom nadsyłanym nieraz z dwuletnim wyprzedzeniem i cierpliwości. Wielokrotnie podkreślał, że: „...jako osoba prywatna jest to najszlachetniejszy czlowiek na świecie”, a po druku „Zbrodni i kary”, mimo kontaktów z innymi wydawcami, traktował siebie: ,... przede wszystkim jako wspótpracownika „Russkiego wiestnika”. ,...Byl lojalny wobec Katkova, lojalny czlowiekowi i redaktorowi. Ale - nic poza tym. [pisał Igor Volgin] Okresowo bliski byl mu patos jego [Katkova] czolowych artykulów, (...) ale podzielać przekonan Katkova, nie byt w stanie". ${ }^{70}$ Dlatego też kontaktując się z tym wydawcą nigdy nie komentował jego poglądów politycznych, a zmieniając w ostatnich latach życia czasopisma, dla których pisał, dowodził złożoności i płynności własnego światopoglądu oraz nieustającego sporu z samym sobą.

\section{Vasilj Kašpirev - „Zaria”}

Przebywający za granicą autor o planach wydania przez V. Kašpireva (1836-1875) nowego pisma „Zaria” dowiadywał się z listów współredaktora Nikolaja Strachova. ${ }^{71}$ Jeszcze przed ukazaniem się pierwszego numeru miesięcznika, wyrażał radość i nadzieję, że będzie on kontynuował i roz- 
wijał kierunek w myśli rosyjskiej, wytyczony przez czasopisma "Vremja” i „Epocha”. ,...Nasza wspólna praca nie umarła [pisał] „Vremia” i „Epocha” przyniosły jednak płody i nowe przedsięwzięcie zmuszone jest zacząć od tego, na czym my zatrzymaliśmy się. To bardzo radosne". ${ }^{72}$ Sympatyzując $\mathrm{z}$ powstałym periodykiem, przekazywał kolegom rady dotyczące organizacji czasopisma, komentował treść poszczególnych numerów, objaśniał popełnione błędy.

W 1869 roku redakcja, za pośrednictwem Strachova, wysłała Dostojewskiemu oficjalne zaproszenie. ,... Odpowiedziatem na ich propozycję, że w każdej chwili gotów jestem nawiqzać z nimi wspótpracę, ponieważ jednak moja sytuacja pieniężna zawsze zmuszala mnie do pobierania zaliczek, a Katkow zawsze mi wyplacal pieniądze naprzód, to również proszę ich, $w$ celu zabezpieczenia mojej sytuacji materialnej o 1000 rubli". ${ }^{73}$

Początkowo Fiodor Michajłowicz planował dostarczyć „Zarii” powieść o objętości około 10 arkuszy, jednak odmowa wysłania tak dużej zaliczki (redakcja dopiero rozpoczynała działalność) skłoniła go do zmiany projektu. W marcu 1869 roku zamierzał napisać krótszy już tekst i zwrócił się o kolejny, niższy zadatek. Pieniądze, wskutek przejściowych trudności finansowych redaktora i nieporozumienia w bankach, nie nadchodzily. „... Od Kaszpiriewa dotychczas ani grosza nie otrzymalem - same obietnice! [pisał zdenerwowany do Majkova] Gdybyś wiedzial w jakiej jesteśmy teraz sytuacji. Przecież jest nas troje - ja, żona, która karmi (...) $i$ dziecko, [córka - Ljubov] które zachorlije i może umrzeć z powodu naszej nędzy. Czyż on [wydawca] myśli, że pisalem mu o swej nędzy dla stylistycznego upiększenia listu? Jak mogę pracować, kiedy na to żeby dostać 2 talary na telegram, zastawilem spodnie! Czort mnie bierz zreszta z moim gtodem. Ale przecież ona karmi dziecko, cóż się stanie, gdy ona ostatnie swoje cieple futerko idzie sama zastawiac do lombardu! (...) Czyż on nie rozumie, że nie tylko mnie ale, i mojq żonę obrazil, obchodząc się ze mnq tak niedbale, wówczas, gdy mu pisatem o potrzebach mojej żony. Zelizyl, zelżyl! On mi ręczyt wlasnym stowem! (...) I oni żadaja ode mnie teraz literatury! Ale czyż jestem w stanie pisać w tej chwili? Chodze i rwę włosy na glowie, a nocami spać nie moge. (...) I w takich warunkach żqdajq ode mnie artyzmu, poezji powiewnej, bez goryczy, wskazuja utwory Turgieniewa, Gonczarowa! Przypatrzcie się sytuacji w jakiej pracuje". ${ }^{74}$

Dopiero Strachovovi udało się załagodzić konflikt. Wytłumaczył przyczyny opóźnienia dostarczenia przekazu i zaproponował w imieniu redaktora spłatę procentów za przetrzymywanie pieniędzy. Dostojewski przyjął uspra- 
wiedliwienie, zdecydowanie odrzucił jednak gest Kašpireva. ,...Nie jestem przecież lichwiarzem. Niejedno może się zdarzyć w życiu" - nadmieniał juź spokojniejszym tonem. ${ }^{75}$

Opowiadanie „Wieczny mąż" pojawiło się w 1 i 2 numerze ,Zarii" w 1870 roku. Jego objętość wróciła do przewidywanego rozmiaru - zajęła nieco ponad 9 arkuszy drukarskich. Pisarz otrzymał za nie 1350 rubli. $^{76}$

Nowy utwór - pierwszą część planowanego ,Żywota wielkiego grzesznika” autor zaoferował „Zarii” na początku 1870 roku: „...Zobowiazuje się, do czasu oddania manuskryptu, [pierwsze miesiące następnego roku] nie naprzykrzać się Redakcji prośbami o dalsza pomoc pieniężnq, wyjawsszy te 1000 mubli, o które prosze. I wreszcie zobowiazuję się nie umrzeć $w$ tym roku." - zwracał się do Strachova. ${ }^{77}$ Kwotę 500 rubli otrzymał on od razu, druga połowa miała być wypłacana w miesięcznych ratach po 100 rubli. Nieoczekiwanie jednak, w sierpniu 1870 roku, Kašpirev zrezygnował ze współpracy, ,...nie chcial już czekać" - pisał twórca „Idioty". ${ }^{78} \mathrm{Na}$ zwrot pobranej zaliczki - 900 rubli - posłużyło Dostojewskiemu honorarium za „Biesy”. W ten sposób zakończyły się kontakty Fiodora Michajloviča z pismem, którego orientacja - jak wielokrotnie podkreślał - była mu najbliższa. ${ }^{79}$

\section{Nikolaj Niekrasow - „Otečestvennye zapiski”}

„... Niekrasow i jego wydawnictwa [zawsze] miaty specjalny urok dla Dostojewskiego" - pisał Stanisław Mackiewicz. ${ }^{80} \mathrm{Na}$ drodze do ich współpracy ciaggle jednak pojawiały się różnorodne przeszkody - ideologiczne, finansowe i osobiste. $\mathrm{Na}$ trwałe udało się je zwalczyć dopiero w 1874 roku.

„,...W rozmowie z V.V. Timofeevoj [Varvara Timofeeva dokonywała korekt artykułów w „Graždanine” - tygodniku redagowanym przez Fiodora Michajloviča] Dostojewski wyrazil chęć wydrukowania w „Otečestvennych zapiskach" nowej powieści, nad która pracowal. Timofeeva zwrócila się z tym zapytaniem do wspótredaktora „Otečestvennych zapisok” (...) G[rigorija] Z. Eliseeva, a on odpowiedziat: (...) < Niech przysyla. Miejsce dla niego u nas zawsze się znajdzie >".

Te wstępne uzgodnienia wkrótce zostały osobiście potwierdzone przez Niekrasowa. W kwietniu 1874 roku odwiedził on pisarza. ,...Ku mojej wielkiej radości uslyszalam, że Niekrasow zaprasza męża do wspólpracy i zamawia u niego dla „, Otečestvennych zapisok" powieść na rok przyszly, obiecujac zaplacić po 250 rubli za arkusz" - wspominała Anna. ${ }^{82}$ 
„Otečestvennye zapiski” - jak wspominano - były czasopismem przeciwnego obozu i przy pierwszej poważniejszej różnicy zdań, kruchemu porozumieniu groziło natychmiastowe zerwanie. „...Choćbyśmy mieli nawet przez ten rok prosić o jatmużnę, to absolutnie nie ustapię $i$ niczego $w$ wymowie powieści nie zmienię" - informował Dostojewski żonę. ${ }^{83}$ Obawy pisarza tym razem jednak nie sprawdziły się: „... Niekrasow przyszedl, aby <wyrazić swój zachwyt po przeczytaniu końca pierwszej części> (...) $W$ ogóle jest [on] strasznie zadowolony. [Fiodor Michjlovič cytował Annie słowa redaktora] <Przyszedlem, aby omówić z panem ciag dalszy. Na litość boskq, niech się pan nie spieszy i niech pan tylko nie popsuje, bo poczatek jest naprawdę bardzo dobry>" ${ }^{.4}$

„Młodzik" - bo o nim była powyżej mowa - ukazywał się w periodyku Niekrasowa w ciagu 1875 roku (nr 1, 2, 4, 5, 9, 11, 12). By wyjaśnić czytelnikom motywy przyjęcia utworu, w styczniowym zeszycie pisma, obok rozdziałów tekstu, pojawiła się obszerna nota redakcyjna. ,...Już kiedyś nadmienialem [pisał główny krytyk „Biesów” Nikolaj Michajlovskij] (...) o dziwnej i godnej ubolewania manii p. Dostojewskiego robienia z przestępczych dzialan mlodych ludzi, (...) tematu swoich powieści. Powiem tylko, że redakcja „Otečestvennych zapisok" podziela mojq opinię dotyczacq manii Dostojewskiego. Tym niemniej „,Mlodzik” drukowany jest w "Otečestvennych zapiskach”. Dlaczego? Po pierwsze, dlatego, że p. Dostojewski jest jednym z naszych najbardziej utalentowanych beletrystów, po drugie, dlatego, że scena u Diergaczewa [mlodzież rozmawia w niej o przyszlości Rosji] ze wszystkimi jej szczególami ma czysto epizodyczny charakter. Jeśli powieść zbudowana bytaby na tym motywie, "Otečestvennye zapiski” zmuszone bytyby odmówić, (...) nawet jeśli on [Dostojewski] jest genialnym pisarzem". ${ }^{85}$

Pomimo niezbyt przychylnego nastawienia pozostałych współredaktorów obie strony nadal chciały razem pracować. Na przełomie 1876 i 1877 roku Fiodor Michajlovič planował dla Niekrasowa kolejny utwór (mógł to być niezrealizowany „Marzyciel”). Otrzymał na ten cel już 1000 rubli zaliczki. Śmierć Niekrasowa w grudniu 1877 roku zniweczyła jednak zamiary Dostojewskiego. Nowi redaktorzy „...kategorycznie odmówili kontynuowania rozmów na ten temat", a pobrane pieniądze zwróciła w 1884 roku żona pisarza. ${ }^{86}$

Wyrazem szacunku i świadectwem ostatecznego pojednania z Niekrasowem - człowiekiem, który jako jeden z pierwszych poznał się na talencie Dostojewskiego - była mowa, wygłoszona przez Fiodora Michjloviča nad grobem poety. W wersji znacznie rozszerzonej ukazała się ona w grudniowym numerze „Dziennika pisarza” w 1877 roku. ${ }^{87}$ 
Olbrzymie kłopoty wypływające z nie uporządkowanego trybu życia literata, dziesiątki niepewnych lat, niestałych i niezbyt wysokich zarobków, pobierania zaliczek, wyczekiwania, proszenia, nie przemyślanych wydatków i długich okresów nędzy - tak w skrócie można podsumować dotychczas scharakteryzowane kontakty wydawnicze pisarza. Trudno wyobrazić sobie, co Dostojewski chciał i mógłby stworzyć mając lepsze warunki...

\section{Dostojewski jako redaktor i wydawca czasopism}

„...Czasopisma to mózg procesu literackiego, literatura zaś to jego dusza" - pisał B. Bursov. ${ }^{88}$ Własne czasopisma posiadali Aleksandr Puszkin, Niekrasow, Lew Tołstoj, Michail Sałtykow-Szczedrin; posiadał je także Dostojewski. Jako dziennikarz i wydawca periodyków dopełniał on tego, co robił twórca genialnych utworów powieściowych: publicysta wspierał, korygował i „pointował” artystę, ułatwiając mu dialog ze współczesnością i rozszerzając możliwość oddziaływania na społeczeństwo. Ta forma wypowiedzi pociagała pisarza od początku jego działalności literackiej, towarzyszyła mu w ciagu całego pracowitego życia, nasilając się zwłaszcza w ważniejszych momentach ideowej i artystycznej ewolucji.

Pierwszą dziennikarską próbą Fiodora Michajloviča, zakończoną niestety tylko napisanym anonsem, miała być praca w „Zuboskale”. Do publicystyki udało się Dostojewskiemu powrócić jednak już niespełna dwa lata później, w kwietniu 1847 roku. Otrzymał wtedy posadę felietonisty w gazecie „SanktPeterburgskie vedmosti". ${ }^{89}$

„...Będę pisać jeden lub dwa felietony na tydzień, [błąd Dostojewskiego, powinno być „na miesiąc"] to jest nie więcej niż za 250-300 rubli asygnacja$m i$ " - informował brata. ${ }^{90}$ Pierwszy z tekstów - podpisany „N. N.” - ukazał się 13 kwietnia, kolejne (sygnowane już inicjałami „F. D.”) opublikowano 27 kwietnia, 11 maja, 1 i 15 czerwca. Po piątym felietonie autor zrezygnował z kontynuowania cyklu. Bez reszty pochłonęła go praca nad „Gospodynia" i planem ,Nietoczki Niezwanowej”.91

\section{Miesięcznik braci Dostojewskich - „Vremja” (1861-1863)}

Po kryzysie światopoglądowym, wywołanym procesem pietraszewców i zesłaniem na katorgę, $w$ atmosferze wielkiego ożywienia ideowego lat sześćdziesiątych, pisarz wraz z bratem Michailem założył pierwsze własne czasopismo - „Vremja”. 
Jeszcze w 1858 roku, wykorzystując liberalną politykę rządu, Michail Dostojewski wystarał się o zezwolenie na wydawanie literackiego i politycznego tygodnika „Vremja”, o objętości około 4 arkuszy drukarskich. ${ }^{92}$ Poważna choroba, finansowe problemy związane z prowadzeniem fabryki wyrobów tytoniowych, wreszcie pertraktacje w sprawie sprzedaży utworów Fiodora i oczekiwanie na jego powrót do Petersburga, sprawiły, że skromny projekt Michaila „ruszył” dopiero wiosną 1860 roku.

Ustalono wówczas, że pismo będzie miesięcznikiem; do 30 arkuszy zwiększono objętość poszczególnych numerów. Poprzedni program dotyczący treści „Vremeni” uzupełniono o zagadnienia ekonomiczne, finansowe i filozoficzne. ${ }^{93}$

Do współpracy bracia zaprosili swoich przyjaciół, z którymi znajomość nawiązali już w latach 40-tych: Aleksandra Miljukova (1817-1897), Alekseja Pleščaeva (1825-1893), Apollona Majkova, Aleksandra Poreckogo (1819-1879). Wielu literatów przeszło do redakcji Dostojewskich po upadku zbliżonego, pod względem ideologicznym, do przyszłej „Vremeni” pisma „Svetoč”. Wśród nich byli m. in. Nikolaj Strachov, Apollon Grigor'ev (1822-1864), Dmitrij Minaev (1835-1889), Jakov Polonskij (1819-1898) i inni. Trzecią - bardzo liczną grupę pracowników zatrudnionych w periodyku stanowili czytelnicy - korespondenci - z Kijowa, Odessy, Nowogrodu, Orenburga i innych rosyjskich miejscowości. W sumie, we „Vremeni” opublikowane zostały teksty ponad stu autorów. ${ }^{94}$

Jednym z podstawowych wyznaczników historiozofii myślicieli skupionych wokół „Vremeni” była tzw. idea ,gleby”. ,...Ich zdaniem, rok 1861, rok reformy chtopskiej zamykal $w$ historii Rosji epoke $\langle$ Piotrowa $\rangle$, epoke niesamodzielnego rozwoju $i$ wpływów cywilizacji zachodnioeuropejskiej. W'́lad za slowianofilami uważali, że [car] Piotr I swoimi reformami <oderwat od gleby > inteligencję rosyjskq jednak wbrew slowianofilom twierdzili, że dzięki temu możliwy stal się w Rosji rozwój cywilizacyjny. Reformy Piotra potraktowali jako konieczność historyczna, jako <owoc naturalny, pożadany przez glebę> rosyjskq. Ponieważ jednak cywilizacja w Rosji <zatoczyla już petny krag>, ponieważ Rosjanie <w petni już jq wykorzystali>, wzięli od niej <wszystko co należalo>, zadaniem epoki następnej staje się < powrót do rodzimej gleby> ucywilizowanej inteligencji rosyjskiej". ${ }^{95}$

Oficjalnym redaktorem nowego przeglądu literacko-politycznego został Michail Dostojewski. Wziął on na siebie większość spraw organizacyjnych i finansowych pisma. ,...Gruba księga przychodów i rozchodów (...) z podpisem (...) <Journal>. Na poliniowanych stronach z lewej- przychód-za- 
pis kwot, otrzymywanych od prenumeratorów, z prawej - rozchód - zapis honorariów dla pracowników, rachunki za papier; drukarnię, korektę, pocztowe optaty przesylek i wiele innych." - tak Vera Nečaeva opisywała księgę redakcyjną $\mathrm{z}$ jego wyliczeniami. ${ }^{96}$

Za naukowe i krytyczne artykuły Dostojewscy płacili autorom od 50 do 100 rubli za arkusz drukarski. Beletrystyka opłacana była w zależności od popularności nazwiska twórcy - Fiodor Michajlovič przykładowo otrzymywał od 200 do 250 rubli za arkusz. Bardzo często, część honorariów regulowano też przy pomocy książek, cygar i wina.9?

Prenumeratę na periodyk prowadziły księgarnie, redakcje czasopism i niektóre z ministerstw oraz urzędów. Roczna opłata za dwanaście zeszytów wynosiła 16 rubli. W przybliżeniu można ustalić, że w 1861 roku „Vremja” miała około 1600 prenumeratorów (dochód wynosił 25000 rubli, rozchód - 29000), w 1862 roku subskrybentów było już ponad 4000 (dochód powyżej 60000 rubli, rozchód 47000). Do momentu zamknięcia miesięcznika - w kwietniu 1863 roku - zamówiłenie złożyło około 3500 osób. ${ }^{98}$

Przyczynę tak dużego powodzenia, jakim cieszyło się nowe pismo, należało upatrywać przede wszystkim w osobie powracającego z katorgi i zesłania, czołowego współredaktora „Vremeni”, Fiodora Dostojewskiego. O znaczącej (choć nie równorzędnej z bratem) roli pisarza w redakcyjnym życiu czasopisma świadczą jego zapisy dotyczące periodyku oraz liczba literackich i publicystycznych tekstów przeznaczonych do miesięcznika, wynoszących w sumie ponad 52 arkusze drukarskie. ${ }^{99}$

Już w pierwszym numerze „Vremeni”, w 1861 roku, pojawiły się utwory Dostojewskiego - były to "Petersburskie senne widziadła wierszem i prozą", rozpoczęto druk „Skrzywdzonych i poniżonych” (nr 1-7). Od zeszytu 4 na łamach miesięcznika zaczęły ukazywać się „Wspomnienia z domu umarłych" (nr 4, 9-11, 1861, nr 1-3, 5, 12, 1862). ${ }^{100}$ Pisarz dla swojego czasopisma przeznaczył też „Paskudną historię” (znaną również pod tytułem „Nieprzyjemna anegdota" - $\mathrm{nr} 11,1862$ ) oraz „Zimowe notatki o wrażeniach $z$ lata” (nr 2 i 3 z 1863 roku).

Oprócz beletrystyki Fiodor Michajlovič zamieszczał w periodyku artykuły, m. in.: „Knižnost' i gramotnost"”, „G. - bov i vopros ob isskustve”, „Dva lagerja teoretikov”, „O novych literaturnych organach i o novych teorijach" i szereg innych. ${ }^{101}$

Wybuch Powstania Styczniowego wywołał w Rosji falę szowinistycznych wystapień antypolskich, którym przewodził wielokrotnie wspominany Michail Katkov. Mimo takiej atmosfery, w pierwszych trzech numerach miesięcznika z 1863 roku, zamieszczone były jedynie suche informacje 
o wydarzeniach w Polsce, bez jakichkolwiek napaści na powstańców i bez solidaryzowania się z działalnością rządu carskiego. Po ukazaniu się zeszytu kwietniowego „Vremja” została zamknięta. Polecenie wydał sam car Aleksander II, a decyzja podyktowana była zarzutem zdrady sprawy rosyjskiej, której dopatrzono się w artykule Nikolaja Strachova - „Fatalna kwestia” (,Rokovoj vopros”).

,....Strachov postanowil poprzeć krwawe stumienie powstania delikatniejszymi argumentami, niż to czynila zwykla rozzuchwalona prasa. [pisał Valerij Kirpotin] $W$ obronie rzqdowej polityki w Polsce wysunal on szereg chytrze wymyślonych historyczno-filozoficznych i religijno-moralnych sofizmatów". ${ }^{102}$ Sens ideowy jego artykułu sprowadzał się do tezy, że wojna polsko-rosyjska jeszcze bardziej wzmocni patriotyzm powstańców i nie przyniesie oczekiwanych przez carat skutków. Najlepszą metodą - dowodził autor - byłaby walka ideologiczna, polegająca na odcięciu Polski od cywilizacji zachodnioeuropejskiej i stopniowym wszczepianiu jej pierwiastków kultury rosyjskiej. Jeśli Polska nie przywróci się do wspólnoty słowiańskiej drogą rusyfikacji - uważał Strachov - powstania będą się powtarzać. ${ }^{103}$

Potraktowanie „Fatalnej kwestii”, jako wystapienia propolskiego i tym samym sprzeniewierzenia się sprawie rosyjskiej było najzwyklejszym nieporozumieniem. Tymczasem „Moskovskie vedmosti” Katkova z gniewem oskarżyły periodyk o niewłaściwe potraktowanie palącego problemu. Dnia 24 maja 1863 roku, decyzją cara, pismo zlikwidowano.

Dla braci Dostojewskich rozpoczęły się długie dni, tygodnie i miesiące żmudnej pracy: likwidacja miesięcznika, spłacanie autorów, pożyczki, starania o zezwolenie na wydawanie nowego pisma. To ostatnie zakończyło się sukcesem pod koniec stycznia 1864 roku. Michail Michajlovič uzyskał wówczas zgodę na redagowanie czasopisma - „Epocha”.

\section{Czasopismo braci Dostojewskich - „Epocha” (1864-1865)}

Początkowo drugi miesięcznik Dostojewskich miał nosić tytuł „Pravda” - nazwę tę jednak zakwestionowały władze. Kolejna propozycja „Počva” także nie zyskała aprobaty. „...Będziemy wydawać „Epochu”; może to i lepiej, dlatego, że wiele osób uważa nazwę „Počva" [czyli "Gleba”] za dziwnq, a nawet taczy to stowo z agronomiq. "Epocha”, tak ,Epocha”" - pisał Michail do brata w połowie stycznia 1864 roku. ${ }^{104}$ Nowy periodyk 
miał mieć objętość 30-35 arkuszy drukarskich. Na jego treść składałyby się trzy działy: literacki, prawny i polityczny. ${ }^{105}$

Z pismem nadal współpracowali A. Grigor'ev, N. Strachov, J. Polonskij, A. Poreckij, A. Pleščaev, A. Miljukov, A. Majkov. Do „Epochi” dołączyli też nowi literaci - przede wszystkim Dmitrij Averkiev (1836-1905) i Nikolaj Solov'ev (1831-1874). W sumie wokół braci Dostojewskich skupionych było około pięćdziesięciu osób. ${ }^{106}$

Zapowiedź pierwszego - podwójnego numeru periodyku pojawiła się w prasie dopiero pod koniec marca 1864 roku. Prenumerata na ten rok była już wówczas dawno zakończona. To trzymiesięczne opóźnienie zaważyło na dalszych losach pisma. Nie bez znaczenia były tu także osobiste kłopoty redaktorów. W lutym zmarła córka Michaila - Varja, a problemy związane z likwidacją fabryki tytoniu i „Vremeni” doprowadziły go do poważnego zadłużenia: „...Kredytodawcy moi rwa ze mnie pieniqdze, a ich jeszcze nie $m a "$ - pisał do brata. ${ }^{107} \mathrm{Z}$ kolei, przebywający w Moskwie Fiodor Michajlovič, opiekował się w tym czasie dogorywającą pierwszą żoną Marią i jedynie listownie wyrażał swoje uwagi dotyczące spraw redakcyjnych. Dopiero po pogrzebie żony i powrocie do Petersburga, w maju 1864 roku, mógł on aktywniej uczestniczyć w „Epoche”.

Dnia 10 lipca 1864 roku zmarł nagle Michail Dostojewski. Jego śmierć była dla Fiodora Michajloviča bardzo bolesnym doświadczeniem: ,...Ile utracilem z Jego odejściem [pisał do brata Andreja] nie będę Ci opowiadat. Ten czlowiek kochat mnie najbardziej na świecie, bardziej niż żonę i dzieci. (...) Wszystkie sprawy rodzinne brata sq w wielkim balaganie. Sprawy w redakcji (...) - wszystko to przyjmuję na siebie. Dlugów masa. U rodziny ani grosza a wszystkie dzieci jeszcze niepelnoletnie". ${ }^{108}$

Zgon wydawcy stał się także nieodwracalnym ciosem dla literackiego przedsięwzięcia. „...Po śmierci brata zostalo zaledwie 300 rubli i z tych pieniędzy zaptacono za pogrzeb. (...) Dlugi wynoszq ok. 25 tysięcy. Wali się cały kredyt pisma. Nie ma ani grosza na jego wydanie, a trzeba wydać jeszcze sześć zeszytów, co kosztuje minimum 18 tysięcy rubli, ponadto zaś zaspokoić wierzycieli, na co trzeba piętnastu tysięcy. Tak więc potrzeba 33 tysięcy, ażeby zamknać rok i ogłosić nowa prenumerate pisma". - informował Dostojewski Vrangelja. ${ }^{109}$ Dla ratowania dobrego imienia Michaila i spłacenia wierzycieli pisarz postanowił kontynuować edycję „Epochi”.

Fiodor Michajlovič musiał zdobyć na ten cel pieniądze oraz znaleźć oficjalnego redaktora: jego nazwisko, jako byłego przestępcy politycznego nie mogło figurować na okładce czasopisma. Sumę 10000 rubli, przeznaczo- 
ną dla siebie w testamencie, otrzymał on od ciotki (siostry matki), Aleksandry Kumaninoj. Obowiązki nominalnego redaktora przejął Aleksandr Poreckij i zaczynając od czerwcowego numeru z 1864 roku, miesięcznik wychodził pod jego redakcja jako wydanie „rodziny M. Dostojewskiego”. ${ }^{110}$

Poreckij przeglądał przygotowywane do druku zeszyty, podpisywał noty od redakcji, kontaktował się z urzędem cenzury, jednak całą wewnętrzną pracą w „Epoche” zajmował się Fiodor Dostojewski. „.... On poprowadzil [czasopismo] energicznie, z ta pieczolowitościq, która odznaczal się przy tego rodzaju zajęciach. (...) Najważniejszym zadaniem stało się dodanie ksiażek za rozpoczęty rok i trzymając się [już] terminów, zyskanie nowych prenumeratorów. (...) Wostatnie miesiace 1864 roku redakcja wypuszczala po dwie książki miesięcznie, tak, że styczeń 1865 roku wyszedl już 13 lutego, a luty w marcu. Drukarnia i papier byly (...) zmienione; korekta zostala poprawiona; malo tego - ksiqżki, (...) rosty objętościowo" - wspominał Strachov. ${ }^{111}$

Całkowicie pochłonięty kłopotami redakcyjnymi pisarz nie miał zbyt wiele czasu na pracę nad własnymi tekstami. W „Epoche” ukazały się tylko dwa beletrystyczne utwory: okrojone przez cenzurę "Notatki z podziemia" (nr 1/2, 4, 1864) i niedokończony „Krokodyl” (opublikowany pod tytułem „Niezwykłe zdarzenie albo przygoda w Pasażu” - nr 2, 1865) oraz sześć artykułów (m. in. „Gospodin Szczedrin ili raskol v nigilistach” i „Kalambury v žizni i literature"). ${ }^{112}$

Miesięcznika nie udało się jednak uratować. Na początku 1865 roku, kwota wpłacona przez subskrybentów wynosiła zaledwie 22000 rubli. Bilans wyglądał następująco: 22000 przychodu, rozchód 29000 gotówką i 9500 wekslami. ${ }^{113}$,... Rozpoczynajac prenumerate, dingi (...) musieliśmy splacać. Placiliśmy z pieniędzy za subskrypcję, myślac, że potem zostanie nam [jeszcze] na wydawanie pisma, ale prenumerata została zakończona $i$, po wydaniu dwóch numerów, zostaliśmy bez niczego... Jeździłem do Moskwy zdobyć pieniqdze, szukalem wspólnika do czasopisma na bardzo korzystnych warunkach, ale oprócz kryzysu w czasopiśmiennictwie mamy też $w$ Rosji kryzys finansowy. Teraz bez pieniędzy, nie możemy już wydawać czasopisma i musimy oglosić czasowe bankructwo, a ja mam, prócz tego, 10000 dlugu wekslowego i 5000 na stowo" - tak Dostojewski opisywal ,agonię" periodyku. ${ }^{14}$

Swoją działalność miesięcznik zakończył wiosną 1865 roku. Pisarz zawarł wówczas umowę z Piotrem Boborykinem (1836-1921), redaktorem „Biblioteki dla čtenija”. ${ }^{115} \mathrm{~W}$ jej wyniku prenumeratorzy „Epochi”, od kwiet- 
nia do końca roku, mieli otrzymywać czasopismo Boborykina. ,...Jednak i na tym ostatnim etapie pech prześladowat ,Epochu”."16 "Biblioteka” także zbankrutowała i czytelnikom periodyku Fiodora Michajloviča nie udało się dostać w zamian ani jednego numeru tego pisma.

Niezrealizowanym kontraktem dwóch redaktorów i wydawców zakończył się dla Dostojewskiego ważny etap jego życia, wzbogacający go, co prawda, o doświadczenia związane z prowadzeniem czasopisma, ale długo jeszcze wywierający decydujący i niekorzystny wpływ na materialne położenie całej rodziny pisarza. ${ }^{17}$

\section{Stanowisko redaktora w „Graždanine” (1873-1874)}

Wkrótce po powrocie pisarza z zagranicy, w 1871 roku, jego przyjaciele - Majkov i Strachov wprowadzili go do kółka księcia Vladimira Meščerskogo (1839-1914), przywódcy rosyjskich konserwatystów i autora bezwartościowych powieści z życia wielkiego świata. Organizował on wówczas tygodnik "Graždanin". ${ }^{118}$

„...Ukończywszy „Biesy” [1872] Fiodor Michajlowicz przez pewien czas byl $w$ wielkiej rozterce, czym ma się teraz zajać. Byl tak wyczerpany pracq nad „Biesami”, że natychmiastowe rozpoczynanie nowej powieści wydawalo mu się niemożliwe. Urzeczywistnienie zaś pomyshu, który narodzil sie jeszcze za granica - pomyshu polegajacego na wydawaniu „Dziennika pisarza” w postaci czasopisma wychodzacego co miesiac nastręczalo duże trudności. Równoczesne wydawanie własnego czasopisma i utrzymywanie rodziny (nie mówią już o splaceniu dlugów) wymagalo dość znacznych środków finansowych. (...) Fiodor Michajlowicz poważnie się wahat i nie wiadomo jakq decyzję by podjal, jeśliby w tym czasie ksiqżę W. P. Mieszczerski nie zaproponowal mu objęcia stanowiska redaktora" - wspominała Anna Dostojewska. ${ }^{119}$

Pisarz za swoją pracę miał dostawać 3000 rubli rocznie, do tego dochodziły też honoraria za napisane artykuły (za każdą linijkę tekstu 7 kopiejek). ${ }^{120}$ „...W sumie mieliśmy okoto pięciu tysięcy rocznie. (...) Otrzymywanie określonej sumy pieniędzy co miesiac mialo (...) swoja dobra strone. Pozwalalo bowiem Fiodorowi Michajlowiczowi oderwać się od klopotów pieniężnych, (...) dzięki czemu mógt bez reszty poświęcić się wziętym na siebie obowiazkom" - dodawała Anna. ${ }^{121}$

Jednym $\mathrm{z}$ zadań stojących przed nowym redaktorem była próba zwiększenia nakładu tygodnika i wzmocnienie jego pozycji na rynku: „... Co mógt 
[Dostojewski] zrobić od razu, żeby poprawić sytuację? Zaprosić nowych autorów? Na to potrzeba bylo czasu, a do wyjścia pierwszego numeru zostały tylko dwa tygodnie [zgodę od Głównego Urzędu do Spraw Druku na objęcie funkcji redaktora pisarz uzyskał w połowie grudnia 1872 roku]. (...) Jedynym wyjściem było samodzielne poprowadzenie jakiegoś działu lub rubryki, który stalby się "gwoździem" wydania. W takich warunkach narodzil się „Dziennik pisarza”. ${ }^{122}$

W ciągu pierwszych dziewięciu miesięcy 1873 roku, na stronach „Graždanina” ukazało się piętnaście części „Dziennika”. W połowie grudnia, w porze rozpoczęcia prenumeraty, wydrukowano jeszcze jeden - ostatni w tym wydawnictwie numer tego „czasopisma w czasopiśmie”.

$\mathrm{Na}$ łamach „Dziennika pisarza” Dostojewski prezentował przede wszystkim swe poglądy na aktualne problemy życia ówczesnej Rosji, choć zamieszczał także artykuły dotyczące polityki zagranicznej. Tam też, w lutym 1873 roku, pojawiło się jego opowiadanie satyryczne „Bobok”, a w lipcu felieton „Małe obrazki”. Otworzyły one cykl późniejszych nowel - prawdziwych osiągnięć Fiodora Michajloviča w dziedzinie małych form pisarskich.

Autor „Zbrodni i kary” niezwykle skrupulatnie podchodził do swoich powinności redaktorskich. Czytał wszystkie artykuły, jakie wpływały do redakcji. Niektóre z nich, nie najlepiej napisane (również teksty samego wydawcy) poprawiał. ,...Jestem w posiadaniu kilku niezdarnych wierszy $z$ widocznymi jednak przeblyskami talentu. Ileż zyskały one dzięki poprawkom Fiodora Michajlowicza" - pisała jego żona. ${ }^{123}$

Poza czytaniem i adiustacją cudzych rękopisów, do obowiązków Dostojewskiego należała też współpraca z drukarnią A. I. Tranšelja, w której składany był „Graždanin”. Jej pracownik - metrampaż Michail Aleksandrov tak opisywał przebieg procesu druku czasopisma i rolę w nim pisarza: „...drukarnia musiała mieć czas na ztożenie [całości], korektę drukarskq, korektę autora, po których Fiodor Michajlovič zezwalal na wysyłkę do cenzora, (...) odbitkę i potem od nowa korektę autora i korektę drukarni, i na koniec dopiero druk". ${ }^{124}$

Latem 1873 roku, kiedy Meščerskij wyjechał z Petersburga, redaktor tymczasowo przyjął na siebie także rozliczenia $z$ autorami. $Z$ tego powodu wielokrotnie dochodziło do listownej, nieprzyjemnej wymiany zdań $\mathrm{z}$ wydawca. , ,... Dzisiaj rano przyszedl telegram i dwa listy od księcia. Chodzi o jego artykul, który mamy zamieścić. Listy jego wydaby mi się nadzwyczaj chamskie. Uskarża się, że numery sq za drogie, że honoraria na nu- 
mer nie powinny przekraczać sumy stu trzydziestu mbli $i$ nie zaplaci ani rubla ponad to i tak dalej. Niech idzie do diabla, nigdy nie pisalem mu, że potrzebuję na honoraria więcej niż tych sto trzydzieści mibli czy też, że mi pieniędzy nie starcza" - informował swą żonę, przebywającą wówczas w miejscowości Stara Russa. ${ }^{125}$ Spięcia i nieporozumienia z księciem wzmagało też częste zwlekanie z przekazaniem pieniędzy Dostojewskiemu przez - specjalnie upoważnionych do tego zadania - dwóch znajomych Meščerskogo. ${ }^{126}$

Z pierwszym okresem redaktorskiej działalności Dostojewskiego wiązało się jedno ważne zdarzenie. Nieopatrznie zamieścił on w artykule Meščerskogo, zatytułowanym „Kirgiscy delegaci w Sankt Petersburgu”, słowa monarchy skierowane do owych wysłanników.

Wedle ówczesnych przepisów cenzury, przemówienia członków rodziny cesarskiej można było drukować wyłącznie za zezwoleniem ministra dworu. ,...Maż nie znat odnośnego paragrafu prawnego. Pociagnięto go do odpowiedzialności sqdowej. Rozprawa bez udziatu przysięglych odbyla sie 11 czerwca 1873 roku w St. Petersburskim Sqdzie Okręgowym. Fiodor Michajlowicz (...) zostal skazany na dwadzieścia pięć rubli grzywny oraz na dwie doby odwachu. (...) Skazanie Fiodora Michajlowicza na areszt przyczynito się do tego, że zawarl znajomość z ówczesnym przewodniczacym St. Petersburskiego Sadu Okregowego, Anatolem Fiodorowiczem Koni, który zrobil wszystko, co było w jego mocy, aby maż mógl odbyć karę w najbardziej dla siebie dogodnym czasie" - wspominała Anna. Stało się to w dniach 21-23 marca 1874 roku. $^{127}$

Ostatni numer "Graždanina", sygnowany nazwiskiem pisarza wyszedł 15 kwietnia 1874 roku. Na jego odejście z redakcji złożyło się kilka przyczyn. Pierwszą z nich były ciagłe nieporozumienia z Meščerskim: „...Ten reakcyjny wydawca, a w dodatku kiepski literat, przysyla do pisma swe konserwatywne brednie, a Dostojewski, (...) nie chce ich drukować" - dodawał B. Bursov. ${ }^{128}$

Lekkomyślność i nieodpowiedzialność księcia w sprawach finansowych, szczególnie dotkliwa dla Fiodora Michajloviča w czasie, kiedy zajmował się on wypłatą honorariów autorskich, także wpłynęła na decyzję pisarza o odejściu z redakcji. Dobrze pamiętał lato 1873 roku i upokarzające dla siebie zastawianie rzeczy osobistych - $\mathrm{m}$. in. zegarka, - żeby tylko terminowo zapłacić swoim współpracownikom.

Trzecim z powodów rezygnacji ze stanowiska, były kłopoty pisarza $\mathrm{z}$ cenzurą. Już wówczas, gdy mianowano go redaktorem naczelnym, 
III Oddział odmówił: „...wzięcia na siebie odpowiedzialności za przyszle posunięcia tej osoby". ${ }^{29} \mathrm{~W}$ marcu 1874 roku minister spraw wewnętrznych oskarżył „Graždanina” o: ,...poglady prowadzace do wzniecenia wrogości przeciwko pewnej warstwie ludności imperium " oraz przekazal pierwsze ostrzeżenie, ,....pod adresem pisma reprezentowanego przez (...) Fiodora Dostojewskiego". ${ }^{130}$ Było to równoznaczne z faktycznym odsunięciem redakıra od jego dotychczasowych obowiązków, pod groźbą likwidacji wydawnictwa. W dniu 19 marca 1874 roku Dostojewski złożył w Głównym Urzędzie do Spraw Druku prośbę o zwolnienie go ze sprawowanej funkcji. Umotywował ją złym stanem zdrowia. ${ }^{131}$

Po raz ostatni kontakt z tygodnikiem pisarz nawiązał w 1878 roku. W numerach 23 - 25 „Graždanina” ukazało się jego opowiadanie „Poslednjaja stranička” (,Iz dačnych progulok Kuz'my Prutkova i ego druga”). ${ }^{132}$

\section{„Dziennik pisarza” jako odrębne wydawnictwo periodyczne}

Już wkrótce po zamknięciu „Epochi”, u Dostojewskiego pojawiła się myśl o wydawaniu nowego pisma. W 1865 roku planował on edycję „Zapisnoj knigi" - projektował jej różne warianty, ustalał nakład, koszty papieru i druku, treść zapowiadających ją ogłoszeń. Istnieje wiele wskazówek, pozwalających przypuszczać, że czasopismo to miało mieć szczególną formę - tę, którą posiadał przyszły „Dziennik pisarza” - mianowicie, w jego skład wchodziłyby wyłącznie teksty tylko jednego autora. ${ }^{133}$

W 1873 roku „Dziennik pisarza” ukazywał się w „Graždanine”. Właśnie dzięki tej rubryce, jak wspominano, nakład tygodnika Meščerskogo zwiększył się trzykrotnie. Jako człowiek doświadczony w prowadzeniu czasopism, Dostojewski nie mógł nie uwzględnić takiej okoliczności. Zatrzymanie znanego i popularnego tytułu musiało gwarantować pomyślność przyszłego - niezależnego już organu.

Nowy „Dziennik” zaczął wychodzić w 1876 roku. „Jest [on] nieprawdopodobnie bogaty w treści, a różnorodność zawartych tu spostrzeżeń jednego czlowieka wprost niepojęta" - pisał o miesięczniku Bursov. ${ }^{134}$ Na poszczególne numery złożyły się bowiem autonomiczne utwory artystyczne - nowele „Chłopczyk na Gwiazdce u Pana Jezusa”, „Chłop Mareusz”, „Stuletnia”, „Potulna” (1876) i „Sen śmiesznego człowieka” (1877), fragmenty prozy wspomnieniowej, artykuły krytycznoliterackie, wreszcie wypowiedzi publicystyczne, stanowiące ponad połowę wszystkich ogłoszonych w czasopiśmie tekstów. W nich Fiodor Michajlovič wiele uwagi poświę- 
cał estetyce, wierze, etyce i kwestiom religijnym oraz podejmował tematy związane z problematyką polityczną, społeczną, obyczajowa.. ${ }^{135}$

Pismo ukazywało się w ostatnich dniach miesiąca, a praca nad zawartością numeru zajmowała redaktorowi około dwóch tygodni. Wydanie dzieliło się na dwie części, te z kolei składały się z od dwóch do sześciu niewielkich artykułów, często dotyczących jednego zagadnienia. ${ }^{136}$

Początkowo, pojawienie się miesięcznika w wielu czasopismach wywołało ironiczne uśmiechy i drwiny. Informowano, że Dostojewski już się wypisał i nic lepszego wydać nie może; inni krytykowali go za wysokie mniemanie o własnej osobie i zuchwałe proponowanie czytelnikom swojego „Dziennika”. Większość publicystów przewidywała, że małe pisemko zginie w masie ówczesnych tytułów. ${ }^{137}$

Wbrew tym opiniom, periodyk spotkał się z uznaniem wielu odbiorców. W 1876 roku na prenumeratę zapisało się 1500 chętnych (roczna opłata wynosiła 2 ruble), w sprzedaży detalicznej (30 kopiejek za numer) rozchodziło się około 4500 egzemplarzy. „Dziennik” dostępny był w księgarniach wielu miast - Petersburga, Moskwy, Kijowa, Odessy, Charkowa, Kazania. ,...Dodam przy sposobności, przez cały czas wydawania mojego Dziennika otrzymywatem i nadal otrzymuję tyle listów pochlebnych dla mnie $i$ tak bardzo mnie aprobujacych i popierajacych w mej pracy, (...) że powiem szczerze: nigdy nie uważalem, że jestem jej godzien" - pisał redaktor w podwójnym - majowo-czerwcowym numerze z 1877 roku. ${ }^{138}$

Po grudniowym zeszycie z 1877 roku Dostojewski zawiesił edycję czasopisma. Był juz zmęczony terminowymi zajęciami, kłopotami z cenzura (kilkakrotnie zatrzymywano mu całe artykuły). „..W tym roku odpoczynku od wydawnictwa periodycznego naprawdę zajmę się tylko pracq nad pewnym utworem artystycznym. [czyli „Braćmi Karamazow”] (...) Ale do „Dziennika" stanowczo chcialbym powrócić za rok. (...) Tym, którzy mi pisali, że porzucam wydawnictwo w najgorętszym czasie, odpowiem, że za rok przyjdzie może czas jeszcze gorętszy, jeszcze charakterystyczniejszy, a wtedy raz jeszcze poshizymy razem dobrej sprawie" - informował czytelników. ${ }^{139}$

"Czas gorętszy, charakterystyczniejszy" nastapił, co prawda, nie za rok, lecz dopiero w czerwcu 1880 roku. Okazją do wydania jedynego numeru "Dziennika” stało się odsłonięcie pomnika Puszkina w Moskwie i „Mowa” o geniuszu, którą pisarz wówczas wygłosił. ${ }^{140}$

Wywarła ona na słuchaczach wstrząsające wrażenie i została przyjęta z pełnym entuzjazmu zachwytem. Dostojewski przeczuwał jednak, że tryumf 
ten nie będzie trwał długo. Obawy okazały się słuszne. Po opublikowaniu pełnego tekstu „Mowy...” rozległy się głosy sprzeciwu ze strony krytyków, należących zarówno do liberalnego, jak i demokratycznego obozu. Fiodor Michajlovič nie chcąc pominąć milczeniem zarzutów stawianych wobec siebie, postanowił kontratakować. Celowi owemu posłużył „Dziennik pisarza".

Sierpniowy numer za szkicem „Puszkin” i komentarzami cieszył się ogromnym powodzeniem. ,...W samym tylko Petersburgu w ciagu trzech dni rozsprzedano 3000 egzemplarzy, a ja wydrukowatem zaledwie 4200. Sadzę, ze przyjdzie mi przygotować drugie wydanie" - pisał Dostojewski do Konstantina Pobiedonosceva. Kolejne 2000 egzemplarzy pisma także rozeszło się W całości. ${ }^{141}$

W 1881 roku autor „Braci Karamazow” zamierzał powrócić do regularnego wydawania miesięcznika. ,... W ostatnich niespokojnych latach intensywnie śledzqc sytuację politycznq Rosji, wiele spraw przemyślal, a wnioski swe $z$ cata swobodq wypowiedzieć mógt tylko w swoim wlasnym czasopiśmie" - nadmieniała żona. ${ }^{142}$ Nowa edycja miała być kontynuowana przez najbliższe dwa lata.

Pisarz zdążył przygotować tylko jeden numer. Ukazał się on - otoczony żałobną opaską - już po jego śmierci. Błyskawicznie sprzedano wszystkie 14000 egzemplarzy (dwa wydania).

Działalność publicystyczną Dostojewski rozpoczął w latach 40-tych, redagowaniem i wydawaniem czasopism zajmował się od 1861 roku do końca życia. Kontaktował się z autorami i komitetami cenzury, sprawował pieczę nad artystyczno-techniczną i finansową stroną wydań. Nawet w czasie pobytu za granicą (1867-1871) nie przestawał interesować się pracą redakcyjną - z uwagą śledził funkcjonowanie miesięcznika „Zaria”, pisał (nie zachowany do naszych czasów) artykuł o Belinskim, projektował wydawanie własnego periodyku. Interwencja cenzury, bankructwo i nieporozumienia z wydawcą nie mogły dać mu należytej satysfakcji w okresie współpracy z pismami „Vremja”, „Epocha” i „Graždanin”. Dopiero „Dziennik pisarza" stał się ukoronowaniem jego wieloletnich wysiłków i zabiegów. Ta własna trybuna pisarska pozwoliła Dostojewskiemu zwieńczyć swoje wcześniejsze dokonania oraz podsumować wszystkie ideowe poszukiwania i rozwiązania. 


\section{Książkowe wydania utworów Dostojewskiego}

Prawie wszystkie $z$ wymienionych wcześniej utworów pisarza doczekały się drugich, a często i następnych wydań. W odróżnieniu od wydawanych we fragmentach pierwodruków, ukazywały się one już wyłącznie w formie książkowej.

Do 1873 roku powieści i opowiadania Dostojewskiego wznawiane były przez zawodowych wydawców, później działalnością wydawniczą przy ogromnej pomocy ze strony żony, zajął się sam Fiodor Michajlovič.

\section{Edycje wydawców profesjonalnych}

Zachęcony sukcesem „Biednych ludzi”, Dostojewski wielokrotnie usiłował wydać utwór własnym nakładem. ,...Wydawać własnym sumptem - to jedyne wyjście. [pisał do Michaila Dostojewskiego] Cudzym - to ryzyko, że się zginie. Księgarze to lajdacy. Forteli maja bez liku, nie znam ich wcale, wiem tylko, że stuża one wylacznie temu, aby mnie nabrać. Najbardziej barbarzyńska jest rzecz nastepujaca. Wydrukuje taki naklad na swój koszt i otrzyma za to ode mnie 350 lub 400 egzemplarzy (cena, która pokrywa mu wydatki). Procent bierze 40 od 100, to znaczy 40 kopiejek srebrem od egzemplarza. (...) To za obrót jego kapitatem i za ryzyko. (...) Ja nie mam prawa sprzedać ani jednego egzemplarza dopóty, dopóki on nie sprzeda wszystkich swoich, albowiem moge narazić go na straty. Sprzeda wszystko, a następnie powie mi, że publiczność się o ksiqżke nie dopytuje $i$ nie ma na niq zbytu. (...) U mnie egzemplarze leżq. A pieniqdze sq mi potrzebne. Kupuje wreszcie taki ode mnie, zamorzywszy mnie uprzednio gtodem, dwie setki egzemplarzy za potowę ceny. Wreszcie sq i takie kanalie, które zatajaja zamówienia z innych miast". ${ }^{143}$

Bieda, zadłużenie i niepowodzenia, którymi kończyły się wszystkie próby zrealizowania edycji autorskiej, sprawiły, że mimo przytoczonej opinii, pisarz zdecydował się odsprzedać prawo do wydania swego debiutu. W zamian uzyskał 200 rubli srebrem. ${ }^{144}$

Książka ukazała się w listopadzie 1847 roku. Wydrukowano ją w drukarni Ėduarda Praca. ${ }^{145}$

Kolejne dzieła Dostojewskiego wznowiono dopiero w 1860 roku. Stało się to już po powrocie autora $\mathrm{z}$ katorgi i zesłania.

Pod koniec 1859 roku, przebywający w Twerze pisarz planował wydanie swoim nakładem dotychczasowych utworów. ${ }^{146}$ Wkrótce jednak jego projekt 
uległ zmianie - dzięki pośrednictwu Aleksego Pleščaeva, edycją zainteresował się wydawca Nil Osnovskij (1811-1871).

Zgodnie z umowa, za prawa do dzieł zapłacił on Dostojewskiemu 2000 rubli. Dwutomowy zbiór miał nakład 2400 egzemplarzy; prawa Osnovskogo wygasały po dwóch latach. Całość ukazała się w pierwszej połowie 1860 roku i kosztowała 3 ruble. ${ }^{147}$ Do pierwszego tomu weszły: „Biedni ludzie”, „Nietoczka Niezwanowa”, „Białe noce”, „Choinka i ślub”, „Mały bohater" oraz przekształcone „Uczciwy złodziej” i „Cudza żona i mąż pod łóżkiem”. Opowiadania „Wieś Stipanczykowo i jej mieszkańcy” i „Sen wujaszka" stanowiły treść tomu drugiego. ${ }^{148}$

Strona tytułowa edycji wyglądała następująco: „Utwory F. M. Dostojewskiego. Wyd. N. Osnovskogo. Moskwa, w drukarni Lazarevskogo instituta vostočnych jazykov, 1860".

Wkrótce po zakończeniu druku „Skrzywdzonych i poniżonych”, autor sprzedał swój nowy utwór drukarzowi Michailu Gavrilovu. O swoim honorarium pisał on w 1861 roku: „... Wziąlem 1000 - więcej wziqć nie można bylo". ${ }^{149}$ Dwutomowe wydanie kosztowało 2 ruble, doliczając wysyłkę - 2,50. Część nakładu sprzedawał sam Dostojewski - za pośrednictwem redakcji „Vremeni” (prenumeratorzy miesięcznika nie płacili za przesłanie książki); pomagał mu także Aleksej Pleščaev - na począıku 1862 roku, podczas pobytu w Moskwie, udało mu się, o czym donosił pisarzowi, „zbyć” 200 egzemplarzy. ${ }^{150}$

Rok później Fiodor Michajlovič nawiązał długotrwałą współpracę z Aleksandrem Bazunovym (1825-1899). Pierwszym utworem, który pojawił się w edycji tego wydawcy i zarazem jego debiutem wydawniczym były „Wspomnienia z domu umarłych”.

„S.-Petersburg, tysiac osiemset sześćdziesiatego dnigiego roku, dnia szesnastego stycznia, Ja niżej podpisany podponucznik Fiodor Michajlovič Dostojewski zawieram Umowe z (...) Aleksandrom Fiodorovičem Bazunovym taka, że Dostojewski wlasny swój utwór pod tytulem „Wspomnienia z domu umarlych" sprzedaje Bazunovu na jedno wydanie, skladajace się z pięciu tysięcy egzemplarzy, za trzy tysiq̨ce pięćset rubli srebrem" - tak brzmiało pierwsze zdanie kontraktu. ${ }^{151}$

Pierwszy tom „Wspomnień...” ukazał się już na początku lutego, tom drugi - pół roku później. ${ }^{152}$ Bazunov prawa wydawnicze do utworu zachowywał przez dwa lata.

W 1867 roku wyszło odrębne wydanie „Zbrodni i kary”. Obok Bazunova, sygnowali je wspominany drukarz E. Prac i właściciel papierni 
J. Vejdenštrauch. Wszyscy troje byli kredytodawcami czasopisma „Epocha” i suma 7000 rubli otrzymana za powieść poszła na wykupienie weksli, które im Dostojewski, próbując ratować periodyk, wówczas wystawił. ${ }^{153}$

Ze wszystkich utworów, właśnie „Zbrodnia i kara” cieszyła się największym powodzeniem za życia autora, a 7000 rubli było najwyższą kwota jaką pisarz kiedykolwiek otrzymał za wznowienie.

Cztery lata później - w 1871 roku - Bazunov wydał „Gracza” i „Wiecznego męża” (na okładce figurował już 1872 rok). Ten drugi tytuł zapoczątkował serię „Biblioteka współczesnych pisarzy”. ${ }^{154}$,....Za prawo wydania w oddzielnej ksiqżce opowiadania , Wieczny maż” (w liczbie 2000 egzemplarzy) księgarz A. F. Bazunow zaplacil nam sto pięćdziesiąt rubli" - wspominała Anna Dostojewska. ${ }^{155}$

Niewielkie sumy - w porównaniu $\mathrm{z}$ honorariami pobieranymi z redakcji czasopism - otrzymywane za utwory, bądź co bądź, bardzo popularne, sprawiły, że Dostojewscy sami zaczęli przygotowywać wydania autorskie. Po 1873 roku już tylko jedna powieść ukazała się w innej oficynie.

Pod koniec 1875 roku, z propozycją wydania „Młodzika” do pisarza zwrócił się księgarz i wydawca Platon Kechribardži (zm. 1882). O przyczynie, dla której Fiodor Michajlovič zgodził się odstąpić wówczas utwór pisał następująco: „...Sprzedaję wydanie w obce ręce jedynie dlatego, ze $w$ chwili obecnej powinienem i zmuszony jestem zaplacić jeden dlug, a sprzedaż wydania „Mlodzika" jest jednym z wyjść z mojej sytuacji". ${ }^{156}$

Dnia 8 listopada 1875 r. zawarto umowę. Dostojewski uzyskał 1200 rubli srebrem, w tym 1000 rubli płatne od zaraz. „Młodzik” miał zostać wydany w nakładzie 2400 egzemplarzy. Kechribardži prawa do tekstu zachowywał na okres trzech lat, liczonych od dnia pojawienia się publikacji. ${ }^{157}$

Powieść do księgarń trafiła na początku lutego 1876 roku. Edycja nie zadowoliła pisarza: ,...Posylam Ci swojq ksiqżke, wydanq przez Kachribardżiego (!) bardzo żle. Wydal, oglosil w gazetach, zawieruszyl gdzieś cały naklad i dopiero po dwóch miesiacach wypuścil na rynek. Wszystko to zaszkodzilo ksiqżce" - nadmieniał w liście do swego brata Andreja. ${ }^{158}$ Taki brak solidności wydawcy spowodował, że kolejną ofertę - dotyczącą tym razem zakupu „Braci Karamazow” - autor zdecydowanie już odrzucił.

\section{Wydanie Stellovskogo (1865-1870) i "Gracz" (1866)}

Po śmierci Michaila Dostojewskiego, pisarz - o czym wcześniej wspominano - zobowiązał się spłacić wszystkie jego i „Epochi” dłu- 
gi. ,... Możliwe, że udaloby się mu wypetnić swój szlachetny zamiar, gdyby byl czlowiekiem ostrożnym i praktycznym. Niestety, za bardzo wierzyl w ludzkqu uczciwość i szlachetność. Gdy później stuchalam relacji świadków o tym, jak Fiodor Michajlowicz wystawial weksle, (...) przerażona bylam jego prawdziwie dziecinna niepraktycznościq. Oszukiwali go i oklamywali wszyscy, którzy tylko mieli czelność i ochotę na to. (...) Oprócz znanych Fiodorowi Michajlowiczowi wspótpracowników (...) zaczęli do niego przychodzić ludzie calkowicie mu nie znani, zapewniają go, że zmarly Michat Michajlowicz mial wobec nich zobowiqzania pieniężne. Prawie nikt nie mial na to żadnych dowodów, zreszta Fiodor Michajlowicz, wierzac w ludzkq uczciwość, nawet ich nie żaqdal. (...) Ludzie brali weksle, przyrzekali czekać i oczywiście (...) natychmiast je protestowali" - wspominała Anna. ${ }^{159}$

Latem 1865 roku, długi nie cierpiące zwłoki opiewały na kwotę 3000 rubli. Wierzyciele grozili zasekwestrowaniem mienia, nawet więzieniem. ,...Gdy wszystkie próby ugodzenia się z wierzycielami spelzły na niczym i Fiodor Michajlowicz doprowadzony byl do ostateczności, calkiem niespodziewanie zjawit się u niego wydawca F[iodor] T[imofeevič] Stellowski z propozycja kupna za trzy tysiace praw na zbiorowe wydanie $w$ trzech tomach jego dziel. Ponadto Fiodor Michajlowicz byl zobowiqzany w ramach tej sumy napisać nowa powieśc". ${ }^{160}$

Kontrakt podpisano 1 lipca 1865 roku. ,...Stellowski przekazal notariuszowi określonq sumę. Pieniqdze te już następnego dnia przeszły do rąk wierzycieli. W ten sposób Fiodor Michajlowicz nic nie otrzymal. Najbardziej oburzajace w tym byto to, ze w ciagu kilku dni pieniadze wrócily znów do Stellowskiego. Okazalo się, że wykupil on za bezcen weksle (...) i przez dwóch podstawionych osobników ściagal z niego pieniqdze" - notowała dalej rozgoryczona Dostojewska. ${ }^{161}$

Trzy tysiące rubli za prawa wydawnicze było ceną znikomą. Przeciwko ,spekulacjom" Stellovskogo wystapiło wówczas nawet bibliograficzne pismo „Knižnyj vestnik”: „...Sześć tytułów utworów pana Dostojewskiego, skladajacych się na treść VII tomu „Zbioru utworów autorów rosyjskich" jest wyraźnym dowodem wydawniczego sprytu wlaściciela cudzych tekstów - pana Stellovskogo. Jak czytelnicy widzq jest to próba zdarcia z jednego wohu, kilku skór" - dodawał publicysta. ${ }^{162}$

$\mathrm{Na}$ pierwszy tom drugiego i ostatniego za życia pisarza zbiorowego wydania (VII wg numeracji serii Stellovskogo - 1865 r.) złożyły się następujące opowiadania i powieści: „Gospodyni”, „Pan Procharczyn”, „Słabe serce”, „Wspomnienia z domu umarłych”, „Biedni ludzie”, „Białe noce” 
i „Uczciwy złodziej”. Tom drugi (VIII - 1865 r.) zawierał: „Skrzywdzeni i poniżeni”, „Niezwykłe zdarzenie albo przygoda w Pasażu”, „Paskudna historia”, „Notatki z podziemia”, "Zimowe notatki o wrażeniach z lata”, wreszcie do tomu trzeciego (XII - 1866 r.) weszły: „Gracz”, „Sobowtór”, "Choinka i ślub”, „Cudza żona i mąż pod łóżkiem”, ,Mały bohater”, „Nietoczka Niezwanowa”, ,Sen wujaszka” i „Wieś Stiepanczykowo i jej mieszkańcy". ${ }^{163}$

Wszystkie tomy nosiły jeden tytuł: „Polnoe sobranie sočinenij. Novoe, dopolnennoe izdanie". ${ }^{164}$ Miały one objętość 30-35 arkuszy drukarskich formatu $4^{\circ}$. Tekst wydrukowano - jak podkreślał wydawca - na podobieństwo edycji zagranicznych w dwóch szpaltach. Prenumeratorzy całej serii za jeden tom płacili 1,50 rubla; pojedyncze książki kosztowały 3 ruble. ${ }^{165}$

Zgodnie z zapowiedzią - autor dokonał zmian w tekstach. Najczęściej polegały one tylko na nieznacznych retuszach stylistycznych, jedynie w przypadku „Sobowtóra" można mówić o poważniejszych przekształceniach. ${ }^{166}$

Najcięższa klauzula umowy dotyczyła obowiązku dostarczenia do 1 listopada 1866 roku nowej, jeszcze nigdzie nie drukowanej powieści o objętości co najmniej 10 arkuszy drukarskich. Gdyby nie została ona oddana w wyznaczonym terminie, Dostojewski musiałby zapłaciłby poważne odszkodowanie. Jeśli zaś utworu nie przekazanoby do 1 grudnia tegoż roku, Fiodor Michajlovič, na dziewięć lat straciłby prawa do swoich dzieł. ${ }^{167}$

Pisarz w 1866 roku, zajęty pracą nad „Zbrodnią i karą”, przewidywał, że nie zdąży wywiązać się z powyższego punktu kontraktu. ,...Dostojewski (...) zaproponowat Stellowskiemu, iż w czerwcu 1866 roku wyplaci mu odszkodowanie. Stellowski odmówil. (...) Poprosil wówczas o odroczenie terminu o trzy miesiqce, lecz znów spotkal się z odmowa. Dostojewski dobrze rozumiat, co się za tym kryje: <Ponieważ Stellowski jest przekonany, że teraz już nie zdqżę napisać powieści, (...) zwlaszcza, że „,Russkij wiestnik” otrzymat ode mnie chyba ledwo polowę, korzystniejsze jest dla niego nie godzić się na przesunięcie terminu i odszkodowanie, ponieważ wówczas wszystko, co napiszę w przyszłości, stanie się jego własnościa>". 168

Na początku października, Fiodor Michajlovič nie miał ani jednego słowa tekstu. Majkov i Miljukov, pragnąc ratować go w biedzie, zaproponowali mu, aby przygotował plan powieści. Każdy z nich napisałby jej pewną część, a Dostojewskiemu pozostałaby tylko redakcja całości i wygładzenie, nieuniknionych przy tej metodzie pracy, „chropowatości”. Pisarz zrezygnował z takiego projektu - nie chcial sygnować swoim nazwiskiem cudzego utworu. Przyjaciele z kolei poradzili mu zatrudnienie stenografa. W tym celu Mil- 
jukov zwrócił się o pomoc do znanego nauczyciela Pavla Olchina. W dwa dni później przysłał on autorowi „Biednych ludzi” najzdolniejszą ze swych uczennic - dwudziestoletnią Annę Snitkin. ${ }^{169}$

Praca rozpoczęła się 4 października. Anna przychodziła o godzinie dwunastej i przez cztery godziny stenografowała. Nocami rozszyfrowywała tekst i nazajutrz przynosiła go do poprawienia.

Pierwsze dyktanda przebiegały w atmosferze napięcia i niepokoju - twórca „Zbrodni i kary” ciagle nie miał przekonania do takiej techniki pisania. „...Ale staranne $i$ dokladne stenogramy jego sekretarki powoli przynosity uspokojenie. Widać bylo wyraźnie, że powieść o graczu [pisarz sięgnął po niewykorzystany pomysł z 1863 r.] udaje się. Dostojewski odkrywat nowa bardzo owocnq metode przerabiania szkicowych notatek, wyraźnie poprawiata sie jakość stylu, wzrastato tempo pracy" - zauważał L. Grossman. ${ }^{170}$

Od 4 do 29 października Fiodor Michajlovič napisał powieść ,,..o objętości siedmiu arkuszy na dwie szpalty dużego formatu, co równa się dziesięciu arkuszom formatu zwykłego". ${ }^{171}$ Stellovskij, który już liczył na odszkodowanie: ,...postanowil dać mata pisarzowi $i$ w ostatniej chwili wyjechal na wies". ${ }^{172}$ „....Fiodor Michajlowicz zaczqł opowiadać mi, [wspominała Anna] ile klopotów miat z dostarczeniem rękopisów Stellowskiemu. Jak przewidzieliśmy, Stellowski użyl wybiegu. (...) Fiodor Michajlowicz pojechal wówczas do biura wydawcy, starając się wręczyć rękopis kierownikowi, lecz ten stanowczo odmówil przyjęcia, mówiqc, że nie zostal do tego upoważniony przez wlaściciela. Do notariusza Fiodor Michajlowicz się spóźnil, w komisariacie w ciagu dnia nie zastal nikogo z wyższych urzędników i poproszono go, aby przyjechal wieczorem. Cały dzień przeszedl mu w zdenerwowaniu i dopiero o dziesiątej wieczorem udato mu się wręczyć rękopis w komisariacie dzielnicy [w której mieszkał wydawca] $i$ uzyskać od rewirowego pokwitowanie". ${ }^{173}$

Powieść zatytułowaną przez Dostojewskiego „Ruletenburg” (od fikcyjnej nazwy miejscowości, w której toczy się akcja utworu), Stellovskij przemianował na „Gracza”. Dzięki niej jednocześnie zlikwidowane zostały dwie groźby ciążące nad pisarzem - groźba ciężkich odszkodowań za niedotrzymanie umowy i groźba samotności: już 8 listopada Anna przyjęła oświadczyny Fiodora.

Nie skończyły się jednak problemy z wydawca. W połowie grudnia 1870 r. w prasie rosyjskiej ukazało się ogłoszenie Stellovskogo o wydaniu „Zbrodni i kary". ${ }^{174}$ 
Punkt ósmy umowy z 1865 roku dopuszczał taką możliwość. Głosił on, że jeżeli wydawca zechce włączyć do pełnego wydania utworów teksty napisane i wydane w 1866 i 1867 roku to może to uczynić, ale tylko po zapłacie honorarium za arkusz - stawka wynosiła tyle rubli, ile kosztował jeden arkusz pozostałych dzieł włączonych do zbiorowej edycji. ${ }^{175}$ Za około 29 arkuszy formatu $4^{\circ}$ (po 30 rubli za arkusz) pisarzowi należało się więc 870 rubli. W przypadku naruszenia powyższego warunku, Stellovskij winien był zapłacić Dostojewskiemu odszkodowanie w wysokości 3000 rubli. ${ }^{176}$

„...I oto powieść byla już wydana, a wydawca nie chcial placić, choć pasierb męża powiadomil go, że jest upoważniony do odbioru pieniędzy. Nie mając pewności, czy pasierb sobie poradzi, Fiodor Michajlowicz poprosil A. N. Majkowa, aby zajat się sprawa tych pieniędzy, nie osobiście oczywiście, lecz powierzajac cala sprawe doświadczonemu adwokatowi" - pisała Anna. ${ }^{177}$

Początkowo Majkov zajmował się sam pertraktacjami ze Stellovskim - w tym celu pisarz przesłał mu, za pośrednictwem konsulatu rosyjskiego w Dreźnie, specjalne pełnomocnictwa. Jego pomoc nie przyniosła jednak rezultatów - Stellovskij zwodził go, obiecywał oddać pieniądze gotówką i wekslami, po czym wyjeżdżał z Petersburga. ${ }^{178} \mathrm{~W}$ tej sytuacji, o uporządkowanie sprawy z nieuczciwym wydawca, Majkov poprosił swego znajomego adwokata - Vasilija Gubina.

Proces sądowy - już z udziałem Dostojewskiego, któremu udało się powrócić do Rosji - rozpoczął się 30 września 1871 r. ${ }^{179}$ Stellovskomu kilkakrotnie wyznaczano syndyka masy upadłościowej (ros. opekun), opisywano i opieczętowywano jego firmę. W październiku 1872 roku, Petersburski Sąd Okręgowy wydał decyzję o zapłacie pisarzowi zaległego honorarium wraz $\mathrm{z}$ odsetkami. ${ }^{180}$ Po wniesieniu apelacji - w listopadzie 1873 roku - sąd postanowił o wypłacie Dostojewskiemu także należnego mu odszkodowania - 3000 rubli. ${ }^{181}$

Jeden z syndyków - Nikolaj Sokovnin - przejął spłatę zasądzonej sumy. W maju 1874 r. zobowiązał się dać roczny weksel (2500 rubli). Powyższy termin płatności - z roku do dziewięciu miesięcy - adwokatowi, reprezentującemu sprawy Fiodora Michajloviča, udało się jeszcze skrócić. ${ }^{182}$

Śmierć edytora - w 1875 roku - Dostojewski podsumował jednym zdaniem: „...Stellowski. Ten nieprzeciętny drapieżca literacki skończyl tak, ze zwariowat i umarl'. ${ }^{183}$

Echa wieloletnich kłopotów ze Stellovskim pisarz przeniósł do „Zbrodni i kary". Wydawca sportretowany został jako kupiec Szełopajew, a droga, 
którą Raskolnikow idzie do domu lichwiarki Alony Iwanownej, dokładnie pokrywa się z trasą, jaką Dostojewski wielokrotnie pokonywał w latach 1865-1866, by osobiście spotkać się ze znienawidzonym „łajdakiem”. ${ }^{184}$

\section{Wydawanie utworów własnym sumptem. „Księgarnia F. M. Dostojew- skiego"}

Już w latach 40-tych Dostojewski nosił się z zamiarem wydawania przekładów i własnych utworów. W listach z tamtego okresu donosił bratu o kolejnych inicjatywach handlowych. Informował o zyskach, jakie przyniosłyby edycje Eugene Sue, Friedricha Schillera, planował wydania „Biednych ludzi”, "Sobowtóra", utworów zebranych. ${ }^{185}$ Skrupulatnie przeprowadzał buchalteryjne wyliczenia - nakładów, kosztów papieru, druku, oprawy. ${ }^{186}$

Do takich przedsięwzięć potrzeba było jednak kogoś praktycznego, znającego się na finansach. Taką osobę pisarz znalazł w drugiej żonie. „,...Mogłaby być dyrektorem banku Rotschilda" - pisał o Annie Ryszard Przybylski. ${ }^{187}$ Właśnie dzięki jej umiejętnościom, w 1873 roku, Dostojewscy rozpoczęli działalność wydawniczą.

„,...Jedna z naszych nadziei na poprawienie naszej sytuacji materialnej (...) byla możliwość sprzedania praw na wydanie ksiażkowe powieści ,Idiota" a później „Biesów”. Mieszkając za granica trudno nam było przeprowadzić tego rodzaju transakcje, nielatwo bylo tego dokonać $i$ wówczas, gdy wróciliśmy do Rosji i mieliśmy okazję do nawiqzania osobistych kontaktów $z$ wydawcami. Wszyscy, do których zwracaliśmy się, proponowali nam bardzo niekorzystne warunki. (...) Za prawo wydania „Biesów" proponowano wszystkiego pięćset rubli, $w$ dodatku płatne ratami w ciagu dwóch lat" - wspominała Anna. ${ }^{188}$

Dostojewska pomału zaczęła „rozpoznawać rynek”. Rozmawiała z drukarzami, dowiadywała się o sposoby płatności za druk, papier, warunki udzielania kredytu, prowizje dla księgarzy, ustalanie wysokości ceny, sposoby reklamowania wydawnictw.

„Debiutanckie” trzy tomy „Biesów” ukazały się w styczniu 1873 r. Wydrukowano je w nakładzie 3500 egzemplarzy, dużą czcionką na atłasowym papierze. Kosztowały 3 ruble 50 kopiejek.

Sprzedaż odbywała się w przedpokoju ich mieszkania i redakcji „Graždanina". Pierwszego dnia rozeszło się sto piętnaście egzemplarzy. W zależności od liczby pobieranych książek, Anna udzielała rabatu: za 10 sztuk dawała dwudziestoprocentową zniżkę, przy większych zamówieniach, rabat wynosił 
25-30\%. Tylko przy zakupie ponad stu egzemplarzy Dostojewska godziła się przyjąć krótkoterminowe weksle; w pozostałych przypadkach księgarze musieli płacić gotówką. ${ }^{189}$

„,...Sprzedaliśmy do końca roku trzy tysiace egzemplarzy. Sprzedaż pozostalych pięciuset ciagnęla się przez dwa czy trzy lata. Wrezultacie, odliczajac rabat księgarski $i$ wszystkie nasze wydatki, pozostalo nam ponad cztery tysiace rubli" - pisała zadowolona żona. ${ }^{190}$

Zdarzały się też i straty - kilku naciągaczy skorzystało początkowo z niewielkiego doświadczenia Anny - oraz sytuacje komiczne. Klienci prosili o „nieczystą siłę”, „czarty”, „diabły”: ,... staruszka piastunka styszqc często podobne znieksztalcenia tytulu powieści skarżyla mi się, (...) że od chwili, gdy w naszym mieszkaniu pojawila sie „, sila nieczysta” (, Biesy"), jej wychowanek (mój syn [Fiodor]) stat się bardziej niespokojny". ${ }^{191}$

Rok później Dostojewscy wydali "Idiotę" (dwa tomy, cena 5 rub.) ${ }^{192}$, potem kolejno pojawiały się: „Wspomnienia z domu umarłych” (1875, 2 rub.), „Zbrodnia i kara” (1877, 2 t. - 3,50 rub.), „Skrzywdzeni i poniżeni” (1879, 2,50 rub.), „Bracia Karamazow” (1881, 2 t. - 5 rub.). W sprzedaży dostępne były także dwa zbroszurowane roczniki „Dziennika pisarza” za lata $1876-1877$ (2,50 rub.).

Wszystkie wymienione tytuły rozchodziły się bardzo dobrze - dla przykładu: w ciagu kilku dni sprzedano 700 egzemplarzy „Wspomnień z domu umarłych”, zaś „Braci Karamazow”, przez cztery dni, około 600 egzemplarzy (ich nakład wynosił 4000; za całe wydanie Anna Grigorevna przewidywała 10000 rubli zysku). ${ }^{193}$

Na początku 1880 roku, małżonkowie postanowili założyć księgamię wysyłkową. O przyczynach zaangażowania się w nowe przedsięwzięcie w następujących słowach pisała Anna: ,...Chociaż z roku na rok nasze sprowy pieniężne wygladaty coraz lepiej $i$ większość dlugów (...) została już splacona, niemniej nasza sytuacja materialna wciqż nie byla ustabilizowana. Życie stawalo się coraz droższe, (...) a Fiodor Michajlowicz uświadamial sobie, iż praca przychodzi mu z coraz większq trudnościa. W dodatku jeszcze jego choroba (rozedma) czyniła postepy i należalo liczyć się z tym, iż ze względu na pogarszajacy się stan zdrowia zmuszony będzie zaniechać na pewien czas pracy literackiej. (...) Dhugo myślalam, czym mogłabym się zajać, aby wesprzeć budżet domowy. Po długim zastanawianiu się i zasięgnięciu rady znajomych przeważyt pomysl zalożenia księgarni dla zamiejscowych klientów, tym bardziej, że dzięki działalności wydawniczej, mialam już pewna praktykę w sprzedaży ksiażek". ${ }^{194}$ 
Ze zrozumiałych względów, księgarnia sygnowana była nazwiskiem pisarza. ,... Wykupiwszy w Izbie Skarbowej „koncesję” Fiodor Michajtowicz przeobrazil się w kupca, czego nie omieszkali wyśmiać w gazetach jego wrogowie". ${ }^{195}$

Ogłoszenie o zainicjowaniu działalności nowej placówki pojawiło się w wielu petersburskich i moskiewskich periodykach. Informowano w nim o możliwości zakupu i wysyłki „najrozmaitszych ksiazzek w języku rosyjskim, podręczników, pomocy naukowych". Księgarnia przyjmowała prenumeratę na wszystkie czasopisma i gazety; prowadziła też sprzedaż autorskich wydań właściciela. Koszta wysyłki wynosiły 10 kopiejek od 1 rubla (np. za książkę kupionąza 2 ruble firma pobierała opłatę w wysokości 20 kopiejek). ${ }^{196}$

Główny trzon odbiorców korzystających z usług księgarni, stanowili dawni prenumeratorzy „Dziennika pisarza”. ,... Oprócz stalego kreggu nabywców bylo niemato klientów jednorazowych. (...) Oczywiście zdarzali się również klienci uciążliwi w rodzaju prenumeratorów jakiś gazet, z których czystego zysku mieliśmy dwadzieścia pięć kopiejek. Jeszcze bardziej dali się nam we znaki klienci, którzy zlecali nam przystanie ksiązek dawno wyczerpanych. Tego rodzaju zleceniodawcom po dhugich i sumiennych poszukiwaniach musielismy zwracać pieniadze" - dodawała Dostojewska. ${ }^{197}$

Pisarz z wielkim zainteresowaniem śledził działalność swojej firmy. Pod koniec każdego miesiąca żona sporządzała dla niego „mały raporcik przychodów i rozchodów". Pierwszy, i ostatni rok funkcjonowania księgarni przyniósł Dostojewskim dokładnie 811 rubli czystego dochodu. ${ }^{198}$

W marcu 1881 roku „Księgarnia F. M. Dostojewskiego” przestała istnieć. „...Gdy po śmierci Fiodora Michajlowicza obwieścilam, że mam zamiar zamknąc księgarnie, wiele osób zaczęto prosić mnie, abym odstapila im moje przedsiębiorstwo. Niektórzy (...) proponowali mi (...) okolo póltora tysiqca mibli". ${ }^{199}$ Anna oferty odrzuciła: czuła się odpowiedzialna za dobre imię firmy i nie chciała nazwiska męża narażać na szwank w przypadku nieumiejętnego, czy nierzetelnego nią zarządzania. Sama zaś powróciła do wcześniejszej działalności wydawniczej, poświęciła jej - jak pisała - „...wszystkie swoje sity i cały swój czas". ${ }^{200}$ Dzięki niej ukazały się $\mathrm{m}$. in. pierwsza kompletna edycja utworów pisarza wraz z pełną biografia, bibliografia prac poświęconych Dostojewskiemu i jego twórczości, antologie z fragmentami opowiadań i powieści przeznaczonymi dla dzieci i wiele innych wydań. 
Wydawcy-księgarze rzadko decydowali się na zakup odrębnego wydania utworu. Dostojewski miał to szczęście - jego powieści i opowiadania nie tylko, że ukazywały się w postaci książkowej, ale często następowało to już w roku zakończenia druku tekstu na łamach czasopism („Skrzywdzeni i poniżeni” - 1861, „Wspomnienia z domu umarłych” - 1862, „Wieczny mąż” - 1871) lub wkrótce potem („Zbrodnia i kara” - 1867, „Młodzik”-1876).

Nieznaczne kwoty - choć nie odbiegające od pozostałych honorariów wypłacanych przez wydawców - a z drugiej strony konieczność spłaty kilkunastotysięcznego długu sprawiły, że pisarz rozpoczął i z powodzeniem kontynuował także własną działalność wydawniczą. Oprócz stopniowej likwidacji roszczeń wierzycieli i kredytodawców, taki rodzaj przedsięwzięcia gwarantował Dostojewskiemu jeszcze jedną ważną rzecz: na zawsze odsuwał od niego możliwość wplątania się w kolejne kabały z nieuczciwymi edytorami, pokroju Stellovskogo.

$$
* * *
$$

Do chwytania za pióro pisarza zmuszała bieda i zaciagnięte zobowiązania. ,.... Nadto obarczony dingami Fiodor Michajlowicz musial sam proponować swe utwory czasopismom i oczywiście otrzymywal za nie znacznie mniej, niż dostawali pisarze materialnie niezależni. (...) W czasie, gdy Fiodorowi Michajlowiczowi płacono za "Zbrodnię i karę" po sto pięćdziesiąt mubli za arkusz drukarski, Turgieniew w tym samym ,Russkim wiestniku" dostawal za swoja powieść po pięćset rubli za arkusz" - wspominała Anna. ${ }^{201}$

Pośpiech, brak czasu i możliwości na wykończenie utworów dręczyły autora. Dodatkowo pracę wstrzymywały jeszcze ataki epilepsji. ,...Bywalo, że pierwsze trzy rozdzialy powieści byly już wydrukowane, czwarty oddany do skladania, piaty - dopiero co nadany na poczcie, szósty - w pisaniu, a pozostałe nie byty nawet obmyślone. Ileż razy widzialam później rozpacz Fiodora Michajlowicza, gdy nagle uświadamiat sobie, ze <zmarnowal tak cenny pomys > i nie ma już możliwości naprawienia tego blędu" - dodawała Dostojewska. ${ }^{202}$

Oddając tekst wydawcy, prawie zawsze Dostojewski spłacał dług. Zmuszało go to do uwzględniania uwag edytora i czynienia - wbrew sobie - znacznych poprawek („Zbrodnia i kara”, „Biesy”).

Sytuacja, w jakiej się znajdował nie sprzyjała nawiązywaniu przyjacielskich kontaktów z wydawcami. Jedynie w przypadku Niekrasowa (w latach 1845-1846 i 1874-1877) i Kašpireva (już po zakończeniu druku „Wiecznego męża”) wyszły one poza sferę zawodową. 
Utwory pisarza ukazywały się nie tylko w „obcych” wydawnictwach. W okresie współredagowania „Vremeni” i „Epochi” oraz pracy w redakcji „Graždanina”, jego teksty, co zrozumiałe, drukowały właśnie te periodyki. Chęć uniezależnienia się od wydawców sprawiła, że Dostojewski zajął się także własną działalnością wydawniczą stworzył też autorski „Dziennik pisarza".

Za życia Dostojewskiego utwory jego publikowało kilkunastu wydawców. Jest to dowód na to, jak bardzo nieustabilizowana była jego droga twórcza, jak bardzo doskwierał mu brak pieniędzy i jak ważna była następna, choćby najmniejsza, zaliczka. Częste zmiany redakcji, z którymi współpracował autor świadczą o jeszcze jednej ważnej rzeczy: wskazują mianowicie na, sygnalizowane już, ciagłe formowanie i modulowanie światopoglądu pisarza. Zjawisko to w następujących słowach ujął André Gide: ,....Konserwatysta, ale nie obrońca tradycjonalizmu; zwolennik cara, wszakże demokrata; chrześcijanin, jednak nie katolik; liberat, lecz nie „postepowiec” - dostatecznie wiele jest powodów, aby sprawial klopot każdej partii". ${ }^{203}$

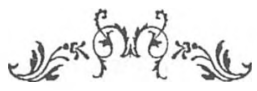

Przypisy:

'F. Dostojewski, Listy, Warszawa, 1979, s.: 168, 265. Nikolaj Strachov (1828-1896) - literat i filozof, pierwszy biograf pisarza. Uważany przez Annę i Fiodora Dostojewskich za przyjaciela domu, po śmierci Fiodora Michajloviča w listach do Lva Tołstoja zniesławił jego pamięć, przypisując mu czyn Mikołaja Stawrogina z Biesów (zgwałcenie nieletniej). Zob. F. Dostojewski, Listy, op. cit., s. 322.

W tekście starano się zachować oryginalną pisownię imion i nazwisk rosyjskich. Odstępstwa uczyniono jedynie w przypadku nazwisk, których spolszczona forma jest powszechnie używana (m. in. F. Dostojewskiego, N. Niekrasowa, I. Turgieniewa). W cytowaniach pozostawiono imiona i nazwiska w takiej postaci, w jakiej używał ich autor. W podobny sposób postapiono $\mathrm{z}$ tytułami rosyjskich periodyków.

${ }^{2}$ B. Mejlach, Talant pisatelja i processy tvorčestva, Leningrad, 1969, s. 261, zob. też

M. Bałchtin, Problemy poetyki Dostojewskiego, Warszawa, 1970, s. 61.

${ }^{3}$ Zob. B. Bursov, Pieniqdze i natchnienie, Życie Literackie, 1971, nr 20, s. 8

${ }^{4}$ B. Urbankowski, Dostojewski: dramat humanizmów, Wyd. 2, Warszawa, 1981, s. 58.

${ }^{5}$ Cyt. za: A. Dostojewska, Mój biedny Fiedia. Dziennik, Warszawa, 1971, s. 14.

${ }^{6}$ L. Grossman, Dostojewski, Warszawa, 1968, s. 306.

${ }^{7}$ Cyt. za: B. Bursov, Osobowość Dostojewskiego, Warszawa, 1971, s. 288.

${ }^{8}$ F. Dostojewski, Pis'ma, [W:] Polnoe sobranie sočinenij v tridcati tomach, T. 28, kniga 1, Leningrad, 1986, s. 86. W latach 30-tych XIX wieku 1 rubel asygnatami (banknotami) wymieniany był wedle oficjalnego kursu na 27 kopiejek srebrem. Zob. przypis 54 
[W:] F. Dostojewski, Skrzywdzeni i poniżeni, Londyn, 1992, s. 358.

" „Repertuar i panteon" - właściwie „Repertuar russkogo i panteon vsech evropejskich teatrov". Petersburskie pismo poświęcone teatrowi, powstałe w 1842 roku. Ukazywało się do roku 1856 (początkowo dwa razy w miesiącu, następnie - od 1848 roku - co miesiąc).

Do 1848 roku periodyk wydawali i redagowali I. Pesockij i V. Meževič. W piśmie publikowano przede wszystkim recenzje z krajowych i zagranicznych przedstawień, materiały poświęcone historii rosyjskiego teatru, artykuły biograficzne i plotki o aktorach. Zamieszczano w nim także oryginalną i thumaczoną beletrystykę". Zob. Russkaja periodičeskaja pečat', pod red. A. Dement'eva, A. Zapadova, M. Cerepachova, T.1: 1702 - 1894, Moskwa, 1959, s.: 286-287, 302-304.

${ }^{10}$ Niestety, w żadnej z dostępnych mi publikacji nie znalazłam informacji o faktycznym wynagrodzeniu, jakie Dostojewski otrzymał za pierwszy przekład.

"Letopis' žizni i tvorčestva Fiodora Michajloviča Dostojewskiego v trech tomach: 1821 -1881 , pod red. N. Budanovoj, G. Fridlendera, T. 1, Sankt Petersburg, 1993, s. 88-89.

12 L. Grossman, op. cit., s. 50.

${ }^{13}$ F. Dostojewski, Listy, op. cit., s. 34. W zacytowanym fragmencie mowa jest m.in. o tym, że pisarz nie otrzyma $z$ redakcji żadnego wynagrodzenia - miało to zwiazzek z powszechnym wówczas zwyczajem niepłacenia debiutantowi, którego pismo przedstawiało publiczności.

${ }^{14}$ Cyt. za: L. Grossman, op. cit., s. 59.

${ }^{15}$ F. Dostojewski, Dziennik pisarza, Warszawa, 1982, T. 3, s. 29.

${ }^{16}$ Cyt. za: L. Grossman, op. cit., s. 61.

${ }^{17}$ Zob. I. Volgin, Rodit'sja v Rossii: Dostojewski i sovremenniki, Moskwa, 1991, s. 382.

${ }^{18}$ F. Dostojewski, Listy, op. cit., s. 43.

${ }^{19}$ "Powieść w dziewięciu listach" miała objętość 1/2 arkusza drukarskiego. Dostojewski dostał za nią 125 rubli asygnacjami; za ogłoszenie ,zainkasował" natomiast 20 rubli srebrem. Zob. F. Dostojewski, Pis'ma, op. cit., T. 28, kniga 1, s. 116. Stawki za arkusz drukarski (nie autorski) były wówczas najpopularniejszą formą rozliczeń między wydawca a pisarzem. Arkusz taki był jednak mierzony nie ilością znaków drukarskich, a liczbą stron $\left(1\right.$ arkusz drukarski $=16$ wydrukowanych stron, najczęściej formatu $\left.8^{\circ}\right)$. Zob. V. Bograd, Žumal „Otečestuennve zapiski" 1868-1884, Moskwa, 1971, s. 727.

20 Tekst humoreski zob. F. Dostojewski, Opowieści fantastyczne, Kraków, 1979, s. 130-154. Autorem partii wierszowanych byl Niekrasow, rozdziały: Il, IV, V i VII napisał Grigorovič; pozostałe - III i VI Dostojewski. Tamże, s. 130. Zob. też: V. Vinogradov, Problema avtorstva i teorija stilej, Moskwa, 1961, s. 206-218.

21 Początkowo Kraevskij cieszył się ogromną sympatią środowiska literackiego przede wszystkim, z uwagi na zakończoną sukcesem, próbę zorganizowania czasopisma, uważanego za „prawdziwą trybunę demokratycznej Rosji". Wielką popularność i kolosalne zyski redaktorowi „Otećestvennych zapisok” udało się zdobyć w głównej mierze dzięki artykułom Belinskogo. Współpraca z Kraevskim ciążyła jednak krytykowi. „... Obarczony ponad miarę czarna robota [recenzowaniem ksiqżek], wyzyskiwany niemilosiemie, z trudem pracowal nad tym, co uważal za najważniejsze". Warunków, w jakich musiał pracować, Belinskij nie wybaczył wydawcy nigdy. Niemal przy każdej okazji wraz z oddanymi mu literatami gorzko wypominał ów bezlitosny wyzysk i eksploatację, samym zaś „Otečestvennym zapiskom", po odejściu z redakcji (1846) otwarcie okazywał niechęć. Zob. W. Śliwow- 
ska, Mikolaj I i jego czasy (1825-1855), Warszawa, 1965, s.: 172, 182 (cytat). Zob. też: 1. Panaev, Wspomnienia literackie, Warszawa, 1955, s.: 135-136, 141, 202-203, 258, 261, 270-271, 367-378, V. Kulešov, Otečestvennye zapiski i literatura 40-godov XIX veka, Moskwa, 1959, s. 210-213.

${ }^{22}$ Cyt. za: B. Bursov, Komentarz do listu Strachowa [Do Tołstoja o Dostojewskim], Miesięcznik Literacki, 1974, nr 10, s. 72.

${ }^{23}$ Autorami pamfletu byli Ivan Turgieniew i Nikolaj Niekrasow. Tak brzmiał początek utworu:

„Oto rycerz smętnej postury -

Dostojewski, uroczy pyszalek,

co na nosie literatury

pqsowieje jak pryszcz dojrzał".

Obszerne fragmenty cytowanej parodii podaje B. Bursov, Osobowość Dostojewskiego, op. cit., s. 103-104. O wierszu, ramce $\mathrm{i}$ innych uwagach pod adresem Dostojewskiego zob. m. in. A. Panaeva, Wspomnienia, Kraków, 1977, s.: 147, 149, L. Grossman, op. cit., s. 79-81, I. Panaev, op. cit., s. 358-360, 1. Volgin, Rodit'sja v Rossii, op. cit., s. 394-419.

${ }^{24} \mathrm{Od} 1847$ roku pisarz brał udział w słynnych wieczorach piatkowych organizowanych przez Michaila Butaševiča-Petraševskogo (1821-1867). Dyskutowano na nich m. in. o literaturze, aktualnych problemach życia w kraju, w tym o ustroju prawnym Rosji, sytuacji chłopów pańszczyźnianych. Stałym tematem, poruszanym na spotkaniach, były też teorie socjalistów utopijnych, zwłaszcza Charlesa Fouriera. Działalność tej idealistycznej grupy młodzieży w najmniejszym stopniu nie zagrażała bezpieczeństwu państwa. Pomimo tego, nocą z 22 na 23 kwietnia 1849 roku nastapiły masowe aresztowania uczestników zebrań. Dostojewskiego początkowo skazano na śmierć, a następnie zamieniono mu karę na cztery lata katorgi. Zob. Dostojewski. Materialy i issledovanija, pod red. V. Bazanova, T. 1, Leningrad, 1974, s. 254-265, W. Śliwowska, Dostojewski w kręgu pietraszewców, Slavia Orientalis, 1958, nr 2, s. 203-222. Jedno z obszernejszych i nowszych opracowań tego tematu znalazło się w książce Igora Wołgina, zob. I. Volgin, Na skraju otchlani. Dostojewski a dwór carski, Warszawa, 2001, s. 69-139.

${ }^{25}$ „Sovremennik” - czasopismo literacko-społeczne wychodzące w Petersburgu w latach 1836-1866. Jego założycielem był Aleksandr Puszkin. W 1847 roku przejęli je Niekrasow i Panaev. Do roku 1848 kierownictwo ideowe nad "Sorremennikiem" pełnił Belinskij. Jego artykuły (jak wcześniej w „Otečestvennych zapiskach") wytyczały program czasopisma - radykalną krytykę rzeczywistości, propagowanie ideałów antypańszczyźnianych i walkę o sztukę realistyczną. Z miesięcznikiem współpracowali: Ivan Turgieniew, Ivan Gončarov, Aleksandr Hercen, Lev Tołstoj. Od drugiej połowy lat 50-tych, dzięki obecności w redakcji Nikolaja Černyševskogo i Nikolaja Dobroljubova, ,Sovremennik” stał się czasopismem skupiającym zwolenników demokracji rewolucyjnej. Władze zamknęły miesięcznik w 1866 roku, po próbie zamachu na cara Aleksandra II. Na temat „Sovremennika” zob. np. V. Bogard, Żurnal „Sovremennik” 1847-1866, Moskwa - Leningrad, 1959, A. Dement'ev, Očerki po istorii russkoj žurnalistiki 1840-1850 gg., Moskwa-Leningrad, 1951, s. 173-177, Istorija russkoj žurnalistiki XVIII-XLX vekov, pod red. A. Zapadova, Moskwa, 1963, s. 242-257, Russkaja periodičeskaja pečat', op. cit., T. 1, s. 240-253, N. Sikorskij, Žurnal „Sovremennik" i krestianskaja reforma 1861 g., Moskwa, 1957.

${ }^{26}$,Illjustrovannyj almanach, izdannyj I. Panaevym i N. Niekrasowym" miał być bezpłat- 
nym dodatkiem dla subskrybentów "Sovremennika" i rekompensować brak rycin w czasopiśmie. Nie trafił on jednak nigdy na rynek. Zakwestionowano w nim $\mathrm{m}$. in. teksty małżeństwa Panaevych i cofnięto dane już zezwolenie na druk (w lutym 1848 roku). Wydany w jego miejsce ,Literaturnyj shomik s illjustracijami" (1849) tylko w nieznacznej części pozwolił na wykorzystanie materiałów z zabronionej edycji. Do dziś „Illjustrovannyj almanach" stanowi bibliofilską rzadkość. Zob. W. Skrunda, Na marginesach wielkiej literatury. Ewolucja rosyjskich almanachów literackich lat 1794-1852, Wrocław, 1974, s. 41.

${ }^{27}$ Cyt. za: Dostojewski. Materialy i issledovanija, pod red. G. Fridlendera, Leningrad, 1985, T. 6, s. 204.

28 "Otećestvennye zapiski" - miesięcznik wydawany w Petersburgu w latach 1839-1884 o charakterze początkowo (do 1858) naukowo-literackim, a następnie także i politycznym. Redaktorem pisma do 1860 roku był Andrej Kraevskij, później współpracował z nim Stepan Dudyškin. Od 1868 roku czasopismo wzięli w arendę i redagowali N. Niekrasow oraz Michail Sałtykow-Szczedrin. Po śmierci Niekrasowa (1877) na jego miejsce wszedł do redakcji Nikolaj Michajlovskij. Obok "Sovremennika", "Otečestvennye zapiski" były najznaczniejszym czasopismem postępowym XIX wieku, wyrazicielem poglądów demokratycznych. W pierwszym okresie (za Kraevskogo), współpracowali z pismem, poza Dostojewskim i Belinskim m. in. N. Niekrasow, I. Panaev, A. Hercen, I. Gončarov, M. Sałtykow. Zob. V. Bogard, Żurnal „, Otečestvennve zapiski” 1839-1848, Moskwa, 1985, A. Dement'ev, op. cit., s.: 112-129, 167-182, 244-247, Istorija russkoj žurnalistiki..., op. cit., s. 226-242, V. Kulešov, op. cit., Russkaja periodičeskaja pečat', op. cit., T. 1, s. 273-286.

${ }^{29}$ Cyt. za: G. Kiràly, Architektonika powieści Dostojewskiego „, Sobowtór", Slavia Orientalis, 1972, nr 3, s. 271.

${ }^{30}$ Cyt. za: I. Volgin, Rodit'sja v Rossii, op. cit., s. 447.

${ }^{31}$ Tamże.

${ }^{32}$, ,...Kraevskij (...) dal mi pieniqudze i obiecal oprócz tego zaplacić wszystkie dlugi do 15 grudnia. Za to pracuję dla niego do wiosny" - pisał Dostojewski do Michaila w grudniu 1846 roku. Zob. F. Dostojewski, Pis'ma, op. cit., T. 28, kniga 1, s. 134.

${ }^{33}$ Tamże, s. 135.

${ }^{34}$ "Podręczny slownik encyklopedyczny" wydawał Karol Kraj, a redagował Al'bert Starčevskij. Dostojewski pracował w nim m. in. nad korektą artykułu o jezuitach. Zob. F. Dostojewski, Pis'ma, op. cit., T. 28, kniga 1, s. 440.

${ }^{35}$ Cyt. za: B. Bursov, Osobowaść Dostojewskiego, op. cit., s. 271.

${ }^{36}$ F. Dostojewski, Pis'ma, op. cit., T. 28, kniga 1, s. 445.

${ }^{37}$ Cyt. za: Dostojewski i ego vremja, pod red. V. Bazanova, G. Fridlendera, Leningrad, 1971, s. 20.

38 Jeszcze przed "Wsiq Stiepanczykowo", w sierpniu 1857 roku, w „Otećestvennych zapiskach" pojawił się, opublikowany pod pseudonimem „M-ij”, „Maly bohater". Utwór (opatrzony tytułem „Bajka dziecięca") napisany został przez Dostojewskiego w twierdzy Pietropawlowskiej latem 1849 roku podczas śledztwa w sprawie pietraszewców. Przed wywiezieniem na Syberię, tekst i pozostałe rzeczy osobiste pisarza władze przekazały Michailu. W dowód wdzięczności za wsparcie duchowe, pomoc finansową i pośrednictwo $\mathrm{w}$ rozmowach $\mathrm{z}$ redakcjami czasopism, Fiodor przelał na brata także prawa autorskie do tego opowiadania. Zob. B. Urbankowski, op. cit., s. 335-336, F. Dostojewski, Pis'ma, op. cit., T.28, kniga 1, s. 304-306. O planach sprzedaży „Wsi Stiepanczykowo” redakcjom „Russkogo vestnika" i ,Sovremennika” zob. F. Dostojewski, Pis'ma, op. cit., T. 28, kniga 1, s.: 295-297, 300, 311, 331-333, 341, 346-347, 353, 500-501, 507 oraz F. M. Dostojewski. 
Materialy i issledovanija, pod red. A. Dolinina, Leningrad, 1935, s.: 439, 512, 520, 557.

${ }^{34}$ O pertraktacjach z Kraevskim dotyczących sprzedaży „Wsi Stiepanczykowo" zob. F. Dostojewski, Pis'ma, op. cit., T. 28, kniga 1, s.: 348, 352, 358, 508-509, F. M. Dostojewski, Materialy i issledovanija, op. cit., s.: 523, 525-527, 530-531.

to F. Dostojewski, Listy, op. cit., s. 182-183.

${ }^{41}$ Zob. tenże, Pis'ma, op. cit., T. 28, kniga 2, s. 421 - 422 oraz G. Culkov, Kak rabotal Dostojewski?, Moskwa, 1939, s. 116 . Kwote 3000 rubli Dostojewski otrzymał po zawarciu lichwiarskiej umowy z wydawcą Fiodorem Stellovskim.

${ }^{42}$ L. Grossman, op. cit., s. 193.

43 "Russkoe slovo" - miesięcznik naukowo-literacki, wychodzący w Petersburgu w latach 1859-1866. Od 1863 roku czasopismo literacko-polityczne. Redaktorem-wydawca do 1862 roku był hrabia Kušelev-Bezborodko, potem Grigorij Blagosvetlov (1824-1880). Periodyk nie miał początkowo żadnej orientacji społeczno-politycznej, wręcz usiłował pomijać milczeniem najważniejsze problemy epoki. W okresie, kiedy pojawił się w nim ,Sen wujaszka", „Russkve slovo" drukowało przeważnie utwory drugorzędnych i nieznanych literatów, a wielu oszustów, dodatkowo wykorzystując naiwność hrabiego, sprzedawało mu rękopisy latami leżące $w$ archiwach innych czasopism, brało pieniądze za teksty oddawane ostatecznie drugim redakcjom itp. Dopiero od maja 1860 roku, kiedy w „Russkim slove" rozpoczał pracę G. Blagosvetlov, pismo przekształciło się, w najbardziej znaczący po „Sovremenniku" organ demokracji rewolucyjnej. Zamknięte zostało (tak jak „Sovremennik”) po nieudanej próbie zabójstwa Aleksandra II podjętej przez Dmitrja Karakozova w 1866 roku. Zob. Isstorija russkoj žurnalistiki..., op. cit., s. 368-371, F. Kuznecov, Publicisty 1860-ch godov, Moskwa, 1969, tenże, Żurnal „Russkoe slovo”, Moskwa, 1965, Russkaja periodičeskaja pečat', op. cit., T. 1, s. 388-394, L. Varustin, Žurnal „Russkoe slovo” 1859-1866, Leningrad, 1966.

${ }^{44}$ F. Dostojewski, Pis'ma, op. cit., T. 28, kniga 1, s. 297.

45 Tamże, s. 299.

46 Tamże, s. 303.

${ }^{47}$ Zob. F. Dostojewski, Listy, op. cit., s. 155-157 i Dostojewski. Materialy i issledovanija, pod red. G. Fridlendera, Leningrad, 1983, T. 5, s. 190-191.

48 "Russkij vestnik" - czasopismo literacko-polityczne, wychodzące w Moskwie w latach 1856-1906 (od 1887 także w Petersburgu), początkowo co dwa tygodnie, od 1861 roku raz w miesiącu. Do 1887 roku jego redaktorem i wydawcą był M. Katkov. Periodyk rozpoczął działalność, jako organ o profilu umiarkowanie liberalnym (współpracowali z nim wówczas Szczedrin, Turgieniew, Tołstoj i inni); po 1861 roku stał się pismem sprzyjającym umocnieniu ideologii absolutyzmu i konserwatyzmowi społeczno-politycznemu. W czasie Powstania Styczniowego podejmował kampanię antypolską, przypisując „polskiej intrydze" rozwój ruchu rewolucyjno-demokratycznego w Rosji. Po 1863 roku, obok nagonki na Polskę „Russkij vestnik” kontynuował walkę z wydawnictwami demokratycznymi i drukował głównie antynihilistyczne powieści. Zob. Isstorija russkoj žurnalistiki..., op. cit., s. 309-310, Slownik pisarzy rosyjskich, pod red. F. Nieuważnego, Warszawa, 1994, s. 337-338, Russkaja periodičeskaja pečat', op. cit., T. 1, s. 340-343 oraz A. Giza, Michal Katkow i jego znaczenie dla umocnienia absolutyzmu carskiego $w$ Rosji $w$ latach 1863-1887, Zeszyty Naukowe Uniwersytetu Szczecińskiego. Rossica Stetinensia, 1988, nr 1, s. 85-102, S. Ščeglovitov, Katkov i ego vremja, Sankt Petersburg, 1888, V. Tvardovskaja, Ideologia poreformennogo samoderžavia, Moskwa, 1978. 
${ }^{49}$ V. Nečaeva, Žurnal M. M. i F. M. Dostojewskich „Vremja” 1861-1862, Moskwa, 1972, s. 268. Zob. też: M. Gus, Idei i obrazy F. M. Dostojewskiego, Izd. 2 dopolnennoe, Moskwa, 1971, s. 189-193, J. Seleznev, Dostojewski, Moskwa, 1981, s. 226-230.

${ }^{50}$ È. Saruchanjan, Dostojewski v Peterburge, Leningrad, 1972, s. 154.

${ }^{51}$ L. Grossman, op. cit., s. 309.

${ }^{52}$ Zob. F. Dostojewski, Pis'ma, op. cit., T. 28, kniga 2, s. 572, tamże, T. 29, kniga 2, s. 222.

${ }^{53}$ Tamże, T. 28, kniga 2, s. 136-139.

${ }^{54}$ Zob. M. Gus, op. cit., s.: 294-295, 323, F. Dostojewski, Pis'ma, op. cit., T. 28, kniga 2, s. 164-167, R. Przybylski, Dostojew'ski i "przeklęte problemy”, Warszawa, 1964, s. 249, L. Grossman, op. cit., s. 334-337.

${ }^{55}$ A. Dostojewska, Wspomnienia, Warszawa, 1974, s. 145.

${ }^{56}$ F. Dostojewski, Listy, op. cit., s. 200.

${ }^{57}$ Tamże, s. 205. Pieniądze od Katkova rozchodziły się nie tylko na pokrycie kosztów utrzymania (łącznie z ruletka) Dostojewskich za granica. Wraz z ich wyjazdem nie uległa wstrzymaniu pomoc finansowa dla rodziny pisarza. O tym, jak wiele znaczyła wówczas każda suma wysłana z moskiewskiej redakcji świadczą słowa Anny: ,....niedawno Fiedi przyszlo coś do glowy i powiedzial, ze Katkow nagle umarl. $<A$ co będzie, jeśli przeczytamy nagle w gazetach, że dnia takiego i takiego umarl Michal Nikiforowicz Katkow? Co my wtedy zrobimy? > Tak bardzo się przerazilam, że zaczelam juz w to wierzvć, i teraz z wielkim lękiem biorę do ręki „Moskovskie vedmosti'". Zob. A. Dostojewska, Mój biedny Fiedia, op. cit., s. 341 .

${ }^{58}$ F. Dostojewski, Listy, op. cit., s. 218-219.

59 Ze względu na spóźnienie, spowodowane atakiem epilepsji, ostatnie rozdziały wraz z epilogiem ,Idioty" ukazały się w specjalnym dodatku do lutowego numeru ,Russkogo vestnika" z 1869 roku. Zob. F. Dostojewski, Pis'ma, op. cit., T. 29, kniga 1, s. 392.

${ }^{60}$ Tamże, T. 28, kniga 2, s. 328.

6l Tenże, Listy, op. cit., s.: 289, 291.

${ }^{62}$ Tamże, s. 248.

63 Rozdział istnieje w dwóch wersjach: „piotrogradzkiej”, będącej kopią oryginału z poprawkami autora oraz w ,moskiewskiej”, w postaci odbitki korektorskiej składu ,Russkogo vestnika". Po raz pierwszy opublikowano go w zbiorze "Dokumenty po istorii literatury i obšćestvennosti. Dostojewski" w 1922 roku. Zob. G. Culkov, op. cit., s. 236-237, L. Grossman, op. cit., s. 410-411, D. Kułakowska, Dostojewski, Warszawa, 1981, s. 244, N. Modzelewska, Pisarz i milość, Warszawa, 1975, s. 326.

${ }^{64}$ Cyt. za: L. Grossman, op. cit., s. 411.

${ }^{65}$ F, Dostojewski, Listy, op. cit., s. 477-478.

Tamże, s.: $512,516$.

${ }^{67}$ B. Bursov, Osobowość Dostojewskiego, op. cit., s. 337. Zob. też: I. Volgin, Poslednij god Dostojewskiego, Moskwa, 1986, s. 239-241.

in F. Dostojewski, Listy, op. cit., s. 633.

(19 Zob. Fiodor Michjlovic Dostojewski. Novye materialy i issledovanija, pod red.

I. Zil'berštejna, L. Rozenbljum, Moskwa, 1973, s. 534-535.

${ }^{70}$ I. Volgin, Poslednij god..., op. cit., s. 244. Zob. też: M. Gus, op. cit., s. 493.

"Zaria" - miesięcznik naukowo-literacki i polityczny, wychodził w Petersburgu w latach 1869-1872. Pismo polemizowało z ideologami demokracji rewolucyjnej, występowało 
przeciw filozofii materializmu. Propagowało idee panslawizmu, nawiązywało do „poczwiennictwa" zapoczatkowanego przez periodyki braci Dostojewskich. Współpracowali z nim: N. Strachov, A. Majkov, Dmitrij Averkiev, Nikolaj Danilevskij i inni. Zob. Russkaja periodičeskaja pečat', op. cit., T. 1, s. 519.

${ }^{72}$ Cyt. za: A. Lazari, „Poczwiennictwo”. Z hadan nad historiq idei w Rosji, Łódź, 1988, s. 75 .

${ }^{73}$ F. Dostojewski, Listy, op. cit., s. 256.

${ }^{74}$ Cyt. za: D. Merežkovskij, Leon Tolstoj i Dostojewski jako ludzie, Lwów, 1904, s. 205-208.

${ }^{75}$ Cyt. za: B. Bursov, Osobowość Dostojewskiego, op. cit., s. 311.

${ }^{76}$ Zob. F. Dostojewski, Pis'ma, op. cit., T. 29, kniga 1, s. 79-80.

${ }^{77}$ Cyt. za: J. Koprowski, Listy Dostojewskiego, Odglosy, 1967, nr 9, s. 7.

${ }^{78}$ F. Dostojewski, Listy, op. cit., s. 274-275.

${ }^{79}$ Tamże, s.: 266, 278.

${ }^{80}$ S. Mackiewicz, Dostojewski, Londyn, [b. r.], s. 178-179. „Otečestvennye zapiski" - zob. przypis 28. W 1868 roku Nikrasow kupił od A. Kraevskogo koncesję na wydawanie miesięcznika i utworzył zespół redakcyjny złożony w zasadzie z byłych pracowników „Sovremennika". Wkrótce dołączyli do niego Aleksandr Skabičevskij i Nikolaj Michjlovskij, którzy zmienili kierunek pisma - periodyk stał się organem ruchu narodnickiego. Krytyka literacka „Otečestvennych zapisok” broniła pisarzy narodników i walczyła przeciwko prasie reakcyjnej, wspierając tendencje wolnościowe, demokratyczne i rewolucyjne. $Z$ czasopismem współpracowali M. Sałtykow, Grigorij Eliseev (współredaktorzy), Gleb Uspenskij, Aleksandr Ostrovskij, Dmitrij Pisarev i inni. „Otečestvennye zapiski" zamknięto w kwietniu 1884 roku za ,szerzenie szkodliwych idei”, przynależność niektórych pracowników do tajnych stowarzyszeń rewolucyjnych i publikowanie (w nielegalnych wydawnictwach) artykułów wstrzymanych wcześniej przez cenzurę. Zob. V. Bograd, Žurnal „Otečestvennye zapiski" 1868-1884, op. cit., Moskwa, 1971, N. Emel "janov, ,Otečestvennye zapiski” N. A. Niekrasowa (1868-1877), Leningrad, 1977, tenże, "Otečestvennye zapiski" N. A. Niekrasowa i M. E. Saltykowa-Szczedrina (1868-1884), Leningrad, 1986, Isstorija russkoj žurnalistiki..., op. cit., s. 409-415, M. Teplin'skij, „Otečestvennye zapiski” 18681884, Južno-Sachalinsk, 1966.

${ }^{8}$ È. Saruchanjan, op. cit., s. 228.

${ }^{82}$ A. Dostojewska, Wspomnienia, op. cit., s. 286.

${ }^{83}$ F. Dostojewski, Aniele, stróżu mój. Listy do żony, Londyn, 1998, s. 213.

${ }^{24}$ Tenże, Listy, op. cit., s. 403 - 404.

${ }^{85}$ Cyt. za: Neizdannyj Dostojewski, pod red. I. Zil'berštejna, L. Rozenbljum, Moskwa, 1971 , s. 66.

${ }^{86}$ Cyt. za: I. Volgin, Poslednij god..., op. cit., s. 246. Zob. też: Dostojewski. Materialy $i$ issledovanija, pod red. G. Fridlendera, Leningrad, 1987, T. 7, s. 203-207.

${ }^{87}$ Zob. F. Dostojewski, Dziennik pisarza, op. cit., T. 3, s. 350-366.

${ }^{8}$ B. Bursov, Osobowość Dostojewskiego, op. cit., s. 458.

"99 „Sankt-Peterburgskie vedmosti” - gazeta, której prawo wydawania miała od 1728 roku cesarska Akademia Nauk. Wychodziła do 1917 roku. Pismo w 1847 roku dzierżawił księgarz i wydawca M. D. Olchin, redagował je dziennikarz, thumacz i cenzor Amplij Očkin (1791-1865). Zob. V. Nečaeva, Rannij Dostojewski 1821-1849, Moskwa, 1979, s. $192-194$. 


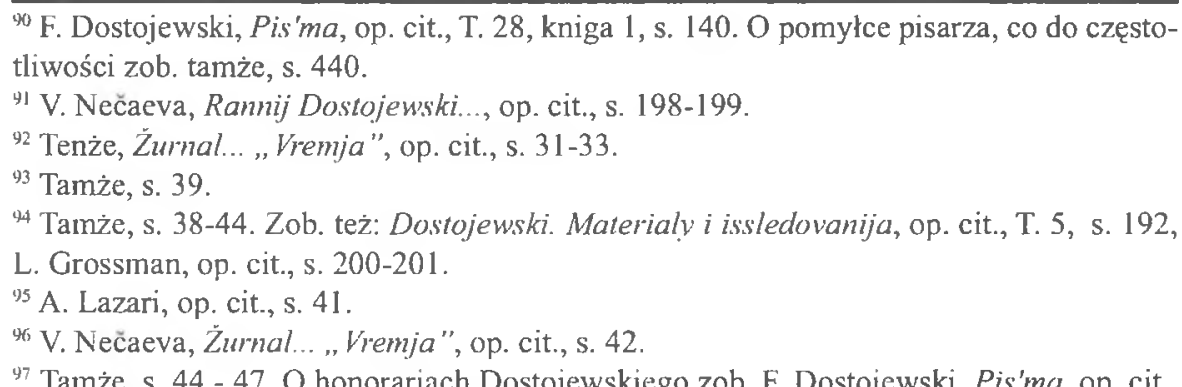
T. 28 , kniga 2, s. 127 , tamże, T. 29 , kniga 1 , s. 28 . Pieniądze otrzymywane przez pisarza za powieści, opowiadania i artykuły dawały mu w sumie około 8000 -10000 rubli rocznic. Zob. tamże, T. 28, kniga 2, s. 118.

${ }^{8}$ V. Nečaeva, Żumal... „Vremja", op. cit., s. 42.

99 Zob. Zapisnye knižki 1860-1862 gg. [W:] Neizdannyj Dostojewski, op. cit., Z notatnika $z$ lat 1860-1862 [W:] F. Dostojewski, Z notatników, Warszawa, 1979 oraz V. Nečaeva, Zurnal... , Vremja", op. cit., s. 17.

${ }^{100}$ „Wspomnienia z domu umarlych" wcześniej drukowane były w gazecie - wydawanej przez Fiodora Stellovskogo i redagowanej przez Aleksandra Gieroglifova (1825-1901) - ,Russkij mir" (nr 67 z 1 września 1860 roku, nr 1, 3, 7 z 4, 11 i 25 stycznia 1861 roku). Publikację zakończono na czwartym rozdziale. W kwietniu 1861 roku, utwór od początku zaczął ukazywać się we „Vremeni”. Zob. Letopis' žizni i tvorčestva..., op. cit., T. 1, s. 295-307, F. Dostojewski, Pis'ma, op. cit., T. 28, kniga 2, s.: 16-17, 372-373. Warto dodać, że przerwa, która nastąpiła między wrześniem 1860 r. a styczniem 1861 r. spowodowana była nieoczekiwaną interwencją cenzury. ,...Publikację nastęnych rozdzialów wstrzymala cenzura, uważają, iz obraz katorgi zostal przedstawiony przez pisarza w < barwach zbyt delikatnych>. Cenzor baron [Nikolaj] Medem żadal wprowadzenia bardziej<mrocznych obrazów>" - pisał Ryszard Przybylski. Zob. R. Przybylski, Dostojewski $i$, przeklęte problemy”, op. cit., s. 131 oraz F. Dostojewski, Pis'ma, op. cit., T. 28, kniga 2, s.: 336-337, 492. Raz jeszcze, w maju 1862 roku, cenzorzy zakwestionowali tekst „Wspomnień." - zatrzymany przez nich ósmy rozdział drugiej czéści utworu pojawił się na łamach pisma dopiero w grudniu tego roku. Zob. V. Nečaeva, Zurnal... „Vremja”, op. cit., s. 294-295.

${ }^{101}$ Zob. G. Culkov, op. cit., s. 95.

${ }^{102}$ Cyt. za: J. Orłowski, Reakcje Dostojewskiego na sprawy polskie, Przeglad Humanistycz$n y, 1982$, nr 5/6, s. 91 .

${ }^{103}$ Zob. B. Mucha, W kręgu „przeklętych problemów” Dostojewskiego, Rocznik Komisji Historyczno-Literackiej, 1984, t. 21, s. 81-93, J. Orłowski, Reakcje Dostojewskiego..., op. cit., s. 85-97, A. Lazari, op. cit., s. 65-68.

${ }^{104}$ Cyt. za: V. Nečaeva, Žurnal M. M. i F. M. Dostojewskich „Epocha” 1864-1865, Moskwa, 1975, s. 11.

${ }^{105}$ Ostatecznie zrezygnowano z wydzielania części prawnej, ze względu na to, że każdorazowo jej zawartość musiałaby być rozpatrywana przez dodatkowy urząd cenzury, znajdujący się przy Ministerstwie Sprawiedliwości. Zob. V. Nečaeva, Žurnal... „Epocha”, op. cit., s. 12.

${ }^{106}$ Tamże, s. 31. 
${ }^{107}$ Cyt. za: tamże, s. 14.

${ }^{108}$ Cyt. za: tamże, s. 16.

${ }^{109}$ Cyt. za: L. Grossman, op. cit., s. 287.

110 V. Nečaeva, Žurnal... „Epocha”, op. cit., s. 17.

"Fiodor Michajlovič Dostojewski v vospominanijach sovremennikov, pod red. V. Grigorenki i in., Moskwa, 1964, T. 1, s. 311.

$1: 2$ Zob. G. Culkov, op. cit., s. 95.

${ }^{113}$ V. Nečaeva, Žurnal... „Epocha”, op. cit., s. 19. Przyczyną niewielkiej liczby prenumeratorów (około 1300), był m. in. fakt, że wielu czytelników, widząc na okładce pisma nazwisko Poreckogo, myślało, że umarł pisarz Dostojewski, autor „Biednych ludz $i$ ”, a nie jego brat. Zob. M. Gus, op. cit., s. 276-277. Fiodor Michajlovič (już za niewiel$\mathrm{kaq} \mathrm{dopłata)} \mathrm{zobowiązany} \mathrm{był} \mathrm{również} \mathrm{dostarczać} \mathrm{periodyk} \mathrm{wszystkim} \mathrm{dawnym} \mathrm{subskry-}$ bentom „Vremeni”, którzy w 1863 roku, zamiast dwunastu, odebrali tylko cztery numery pierwszego miesięcznika Dostojewskich. Zob. F. M. Dostojewski. Materialy i issledovanija, op. cit., s. 578.

${ }^{114}$ Cyt. za: V. Nečaeva, Žurnal... „Epocha”, op. cit., s. 20.

115 „Biblioteka dla čtenija" - czasopismo poświęcone piśmiennictwu, naukom, sztukom, przemysłowi, nowościom i modzie. Wychodziło w Petersburgu w latach 1834-1865, do 1864 roku co miesiąc, w 1865 roku jako dwutygodnik. W 1863 roku jego redaktorem i wydawcą został P. Boborykin. Przez caly okres ukazywania się, periodyk był: ,...dostawca <lekkiego czytania> dla mieszczaństwa". W 1865 roku pismo zbankrutowało. Zob. Russkaja periodičeskaja pečat', op. cit., T. 1, s. 230-231.

116 V. Nečaeva, Žurnal... „Epocha”, op. cit., s. 21.

${ }^{117}$ Zob. F. Dostojewski, Pis'ma, op. cit., T. 28, kniga 2, s.: 228-229, 255, 328-329, tanże, T. 29, kniga 1, s.: 27-29, 90-91, 210 . Jeszcze w 1876 roku pisarz oddawał jednemu $z$ wierzycieli stary dhug za papier w wysokości 1100 rubli. Tamże, T. 29, kniga 2, s. 71.

118 "Graždanin" - reakcyjny tygodnik polityczny i literacki, ukazywał się w Petersburgu w latach 1872-1914, w roku 1882 i od 1885 dwa razy w tygodniu. Założycielem i wydawcą pisma był książę Meščerskij, w 1872 roku redagował je Grigorij Gradovskij (1842-1915), od stycznia 1873 roku do kwietnia 1874 roku Dostojewski, a następnie Viktor Pucykovič (1843-1909). Jego odbiorcami było głównie duchowieństwo i wyższa administracja. Z czasopismem współpracowali: Majkov, Strachov, Poreckij, późniejszy Oberprokurator Świątobliwego Synodu - Konstantin Pobiedonoscev (1827-1907), działacz państwowy Tercjuš Filipov (1825-1899) i inni. Zob. Isstorija russkoj žumalistiki..., op. cit., s. 489-490, Russkaja periodičeskaja pečat', op. cit., T. 1, s. 546-547, Dostojewski. Materialy i issledovanija, pod red. G. Fridlendera, T. 11, Sankt Petersburg, 1994, s. 246-253.

${ }^{119}$ A. Dostojewska, Wspomnienia, op. cit, s. 267-268.

${ }^{120}$ Neizdannyj Dostojewski, op. cit., s. 338.

${ }^{121}$ A. Dostojewska, Wspomnienia, op. cit., s. 268.

${ }_{122}$ Dostojewski. Materialy i issledovanija, pod red. G. Fridlendera, T. 13, Sankt Petersburg, 1996, s. 126. W ciągu roku nakład rzeczywiście wzrósł z 1000 do 3000 egzemplarzy. Tamże, s. 121 .

${ }^{123}$ A. Dostojewska, Wspomnienia, op. cit., s. 276.

${ }^{124}$ Cyt. za: Fiodor Michajlovič Dostojewski. Novye materialy.., op. cit., s. 134.

${ }^{125}$ F. Dostojewski, Aniele, stróżu mój, op. cit., s. 116.

${ }^{126}$ Neizdannyj Dostojewski, op. cit., s. 338-340. 
${ }^{127}$ A. Dostojewska, Wspomnienia, op. cit., s.: 278, 283-284.

${ }^{128}$ B. Bursov, Osobowość Dostojewskiego, op. cit., s. 504. „... Nie mógt [Dostojewski] usunq̨́ artykulów samego wydawcy, który (...) podpisywal swe polityczne pouczenia zalotnym pseudonimem < Przystojna Kobietka $>$. [pisał Stanisław Mackiewicz] Dostojewski zżmal się na te elukubracje, pisane z wyniosla niedbalościq o dokladność faktów i dat historycznych, i przerabial je tak, ze sam autor nie mógt ich poznać, o co powstawaly zrozumiałe scysje". S. Mackiewicz, op. cit., s. 171.

${ }^{129}$ L. Grossman, op. cit., s. 430.

${ }^{130}$ Tamże, s. 431.

${ }^{13 !}$ F. Dostojewski, Pis'ma, op. cit., T. 29, kniga 1, s. 547, Dostojewski. Materialy i issledovanija, op. cit., T. 11, s. 248.

${ }^{132}$ D, Grišin, Dnevnik pisatelja F. M. Dostojewskiego, Melbourne, 1966, s. 186.

${ }^{133}$ V. Nečaeva, Zurnal... „Epocha”, op. cit., s. 226-227.

${ }^{134}$ B. Bursov, Osobowość Dostojewskiego, op. cit., s. 505.

${ }^{135}$ Zob. D. Grišin, op. cit., s. 137 - 138 oraz F. Dostojewski, Dziennik pisarza, op. cit., T. 1 , s. $10-14$.

${ }^{136}$ D. Grišin, op. cit., s. 153.

${ }^{137}$ Fiodor Michajlovič Dostojewski v vospominanijach..., op. cit. T. 2, s. 238-239.

${ }^{138}$ F. Dostojewski, Dziennik pisarza, op. cit., T. 3, s. 131. O nakładzie "Dziennika” zob. Fiodor Michajlovič Dostojewski. Novye materialy..., op. cit., s. 446-447.

${ }^{139}$ F. Dostojewski, Dziennik pisarza, op. cit., T. 3, s. 366.

${ }^{140}$ Wystapienie to stało się niejako testamentem pisarza, zawierającym jego program ideowy oraz próbę historiozoficznego ujęcia dziejów duchowych społeczeństwa rosyjskiego. Poczatkowo „Mowa o Puszkinie” miała ukazać się w „Russkim vestniku” i wypełnić przedhżającą się przerwę w publikowaniu „Braci Karamazow”. Dostojewski zmienił jednak zdanie i tekst - „świeży ślad wydarzeń" - po raz pierwszy wydrukowała gazeta Katkova „Moskovskie vedmosti” (nr 162 z 13 czerwca). Zob. I. Volgin, Poslednij god..., op. cit., s. 312-315.

${ }^{14 !}$ F. Dostojewski, Korespondencja... z Pobiedonoscewem, Literatura na Świecie, 1981, nr 2, s. 295.

${ }_{142}$ A. Dostojewska, Wspomnienia, op. cit., s. 417.

${ }^{143}$ F. Dostojewski, Listy, op. cit., s. 54.

144 Tenże, Pis'ma, op. cit., T. 28, kniga 1, s. 144.

${ }^{145}$ Dostojewski. Materialy i issledovanija, op. cit., T. 6, s. 4.

${ }^{146}$ Zob. F. Dostojewski, Pis'ma, op. cit., T. 28, kniga 1, s.: 340-341, 349-351.

${ }^{147}$ F. M. Dostojewski. Materialy i issledovanija, op. cit., s. 448-450.

${ }^{148}$ Dostojewski złączył wątki opowiadań „Cudza żona” i ,Zazdrosny maż” oraz „Rasskazy byvalogo čeloveka”, „Otstavnoj” i ,Uczciwy zlodziej”. W ten sposób powstały dwa teksty: "Cudza żona i maż pod lóżkiem" i "Uczciwy zlodziel”. W poprawionych wersjach funkcjonują one do dzisiaj. Zob. F. Dostojewski, Wieczny maż $i$ inne utwory, Londyn, 1993, s. 385, tenże, Paskudna historia i inne utwory, Londyn, 1993, s. 360 - 361.

${ }^{149}$ Tenże, Pis'ma, op. cit., T. 28, kniga 2, s. 20.

${ }^{150}$ F. M. Dostojewski. Materialy $i$ issledovanija, op. cit., s. 455.

${ }^{151}$ F. Dostojewski, Pis'ma, op. cit., T. 28, kniga 2, s. 337.

152 Tamże, s. 492.

${ }^{153}$ Tamże, s.: 229, 255, tamże, T. 29, kniga 1, s.: 90 - 91, 97, 211. 
${ }_{154}$ Zob. Letopis'žizni i tvorčestva..., op. cit., T. 2, s. 302.

${ }^{155}$ A. Dostojewska, Wspomnienia, op. cit., s. 269.

${ }^{156}$ F. Dostojewski, Pis'ma, op. cit., T. 29, kniga 1, s. 64.

${ }^{157}$ Treść umowy zob. tamże, s. 182.

${ }^{158}$ F. Dostojewski, Listy, op. cit., s. 423.

${ }^{159}$ A. Dostojewska, Wspomnienia, op. cit., s. 227 - 228.

${ }^{160}$ Tamże, s. 32.

${ }^{161}$ Tamże. Zob. też: F. Dostojewski, Pis'ma, op. cit., T. 29, kniga 1, s. 210 - 213, S. Mackiewicz, op. cit., s. 114.

${ }^{162}$ Cyt. za: V. Etov, Dostojewski, Moskwa, 1968, s. 143.

${ }^{163}$ Neizdannyj Dostojewski, op. cit., s. 199 - 200. Zob. też ogłoszenia wydawnicze [W:]

F. Dostojewski, Zimnija zametki o letnich vpečatlenijach, Novoe prosmotrennoe izd., Sankt Petersburg, 1866.

${ }^{16.4}$ Dostojewski. Materialy i issledovanija, op. cit., T. 6, s. 5 - 6.

${ }^{165}$ F. Dostojewski, Zimnija zametki..., op. cit.

$166{ }^{2}<$ Sobowtór $>$ [pisał Przybylski] nie dawal Dostojewskiemu spokoju”. Już w 1859 roku planował przeróbkę tego utworu. „...Wierzaj mi bracie, że jeśli poprawię, opatrze przedmowq będzie to zupelnie nowa powieść" - informował Michaila. Do wydania z 1860 r. nie zdążył on jednak uczynić projektowanych zmian. Dopiero w $1866 \mathrm{r}$. dokonał skrótów i starannej korekty stylistycznej tekstu - usunął m. in. elementy parodii literackiej i streszczenia akcji zapowiadające każdy z rozdziałów. Zob. R. Przybylski, Dostojewski $i$ „,przeklęte problemy”, op. cit., s.: 84 - 85, 92 (cytaty, s. 84), G. Culkov, op. cit., 30 - 41. W wersji z lat 60-tych ,Sobowtór" funkcjonuje do dzisiaj.

${ }^{167}$ F. Dostojewski, Pis'ma, op. cit., T. 28, kniga 2, s. 160.

${ }^{16 i}$ L. Grossman, op. cit., s. 344.

${ }^{169}$ Zob. A. Dostojewska, Wspomnienia, op. cit., s. 33, S. Mackiewicz, op. cit., s. 121-122, B. Urbankowski, op. cit., s. 51 - 52.

${ }^{170}$ L. Grossman, op. cit., s. 347.

${ }^{171}$ A. Dostojewska, Wspomnienia, op. cit., s. 42.

172 B. Urbankowski, op. cit., s. 52.

${ }^{173}$ A. Dostojewska, Wspomnienia, op. cit., s. 47.

174 „Zbrodnia i kara” stanowiła czwarty tom wydania zbiorowego. Mogła być wydana przez Stellovskogo dopiero w 1870 roku - 31 grudnia 1869 r. wygasały prawa do niej wydawcy Bazunova. Z kolei, prawa do utworów Dostojewskiego, Stellovskij tracił 31 grudnia 1871 roku. Zob. F. Dostojewski, Pis'ma, op. cit., T. 29, kniga 1, s.: 76, 86.

${ }^{175}$ Tamże, s. 173.

${ }^{176}$ Tamże, s. 104.

${ }^{177}$ A. Dostojewska, Wspomnienia, op. cit., s. 208.

${ }^{178}$ F. Dostojewski, Pis'ma, op. cit, T. 29, kniga 1, s.: 174, 451.

${ }^{179}$ Tamże, s. 474.

${ }^{180}$ Letopis'žizni i tvorčestva..., op. cit., T. 2, s.: 321, 325, 331, 340, 355. Zob. też: Neizdannyj Dostojewski, op. cit., s. 348.

${ }^{181}$ Dostojewski. Materialy i issledovanija, op. cit., T. 7, s. 284.

182 Tamże, s. 285. Co do dalszych „losów” roszczeń egzekucyjnych, dostępne mi publikacje milczą. Wiadomo, że do października 1874 r. Sokovnin - przebywający w Samarze - pieniędzy nie zwrócił. Niewykluczone, że nie zostały one oddane wcale, bowiem 
w kwietniu 1875 roku Stellovskij zmarł. Zob. Letopis' žizni i tvorčestva..., op. cit., T. 2, s.: $431,434,490,515$.

${ }^{183}$ F. Dostojewski, Z notatników, op. cit., s. 284.

${ }^{184}$ Dostojewski. Materialy i issledovanija, op. cit., T. 13, s. 236. Określenie „łajdak” pojawia się m. in. w liście z marca 1870 r. Zob. F. Dostojewski, Listy, op. cit., s. 274.

${ }^{185}$ F. Dostojewski, Pis'ma, op. cit., T. 28, kniga 1, s.: 84-88, 127, 131-133, 141, 340-341, 349-350.

${ }^{186}$ Zob. np. B. Bursov, Osobowość Dostojewskiego, op. cit., s. 252 - 253.

${ }^{187}$ A. Dostojewska, Mój biedny Fiedia, op. cit., s. 10.

${ }^{188}$ Tenże, Wspomnienia, op. cit., s. 269.

${ }^{189}$ Tamże, s. 270 - 275.

${ }^{190}$ Tamże, s. 275.

191 Tamże, s. 275 - 276.

${ }^{192}$ Początkowo, przebywający za granica pisarz, zamierzał odsprzedać prawa do wydania „Idioty" zawodowym wydawcom, m. in. A. Bazunovu, M. Gavrilovu, F. Stellovskomu. Najbardziej zaawansowane rozmowy toczyły się z tym ostatnim edytorem - upoważniony pasierb Pavel Isaev miał przekazać powieść za 1000 rubli, powstał już wstępny projekt umowy. Wskutek kłopotów zwiazanych z wyegzekwowaniem honorarium za ,Zbrodnię i karę" pertraktacje przerwano. Zob. F. Dostojewski, Pis'ma, op. cit., T. 29, kniga 1, s.: 35, 43, 75-79, 81-87, 100, 104-105, 116, 372, 384-386, 416-419, 422.

${ }^{193}$ Zob. F. Dostojewski, Aniele, stróżu mój, op. cit., s. 329, I. Volgin, Poslednij god..., op. cit., s. 360 .

${ }^{194}$ A. Dostojewska, Wspomnienia, op. cit., s. 389 - 390.

195 Tamże, s. 390.

${ }^{196}$ Zob. Fiodor Michajlovič Dostojewski. Novye materialy..., op. cit., s. 332.

${ }^{197}$ A. Dostojewska, Wspomnienia, op. cit., s. 391.

198 Tamże.

199 Tamże, s. 392.

${ }^{200}$ Tamże.

${ }^{201}$ Tamże, s. 85-86.

202 Tamże, s. 86.

${ }^{203}$ Cyt. za: J. Koprowski, Listy Dostojewskiego, op. cit., s. 7. 